\title{
REASSESSING THE ECONOMIC EFFICIENCY OF COMPENSATORY DAMAGES FOR BREACH OF CONTRACT
}

\author{
Daniel A. Farber*
}

LTHOUGH punitive damages are often awarded for deliber-
ate wrongdoing in tort cases, ${ }^{1}$ contract law regards deliberate
breacl of a contractual promise with equanimity, perliaps even
witl favor. ${ }^{2}$ Contract damages are designed to put the plaintiff in
precisely the same position as would performance of the contract, ${ }^{3}$
not to deter nonperforinance. ${ }^{4}$ Under this strict-compensation
standard, parties liave an incentive to breach if the profits from
breach exceed the plaintiff's damages. Deliberate breacl of a
promise may be morally objectionable, ${ }^{5}$ but no legal penalty ac-

* Assistant Professor of Law, University of Illinois.

The author wishes to thank Marion Benfield, Donald Harris, and Paul Fellows for their critical reading of earher versions of this article, and Elaine Shoben, for her helpful comments in the early stages of the research. He also wishes to thank his research assistant, John Colombo, for his able and diligent assistance.

1 See W. Prosser, HandBook of THE LAW of TORTs § 2, at 9-14 (4th ed. 1971).

2 In addition to the general unavailability of punitive damages, see note 4 infra, special requirements of foreseeability of injury and certainty of damages limit recovery for breach of contract; much more hiberal rules are available in tort actions. For a criticism of these limitations on contract damages, see Schiro, Prospecting for Lost Profits in the Uniform Commercial Code: The Buyer's Dilemmas, 52 S. CAL. L. REv. 1727, 1750-75 (1979). All of these limitations apparently originated in the eighteenth and nineteenth centuries. See $\mathrm{M}$. Horwitz, The Transformation of Ambrican Law, 1780-1860, at 166-67 (1977); L. Friedman, Contract Law in America: A Social and Economic Case Study 124-30 (1965).

2 Virtually every important treatise states this principle in almost identical language. See J. Calamari \& J. Perillo, The Law of Contracts 521 (2d ed. 1977); 5A A. Corbin, ConTRACTS § 992, at 5 (1964); D. DoBes, HANDBOOK ON THE LAW of REMEDIES 786 (1973); J. Murray, Contracts 438 (1974); $11 \mathrm{~S}$. Williston, A Treatise on the Law of Contracts $\S$ 1338, at 198 (3d ed. 1968); Farnsworth, Legal Remedies for Breach of Contract, 70 Colum. L. REv. 1145, 1147-48 (1970). According to Fuller and Perdue, courts never "knowingly put the plaintiff in a better position than he would have occupied had the contract been fully performed." Fuller \& Perdue, The Reliance Interest in Contract Damages (pt. 2), 46 Yale L.J. 52, 79 (1936).

- See Farnsworth, supra note 3 , at $1145-47,1216$. Thus, punitive or exemplary damages are generally unavailable. See 5 A. CoRBIN, supra note 3, § 1077, at 437-46; D. DoBBs, supra note 3, at 818; J. MURRAY, supra note 3, at 470-71. As Justice Holmes noted almost 80 years ago, the motive behind the breach is generally irrelevant. See Globe Ref. Co. v. Landa Cotton Oil Co., 190 U.S. 540, 544 (1903).

- See J. Rawls, A Throry of Justice 344-50 (1971). See also Birmingham, Breach of Contract, Damage Measures, and Economic Efficiency, 24 RuTGers L. Rev. 273, 281 (1970). 
companies it.

Several commentators have used economic theory to justify this disparity between law and morality. ${ }^{6}$ Their analysis has received the powerful support of the recently completed Second Restatement of Contracts. ${ }^{7}$ Briefly, the analysis is that courts should not penalize breach, because breach may be economically more efficient than performance. If the defendant is in a better position after fully compensating the plaintiff, the breach is socially desirable. ${ }^{8}$

This theory of contract dainages, however, does not fully comport with reality. For instance, widespread reports of dissatisfaction with the quality of many goods and services ${ }^{9}$ indicate that the availability of compensatory damages does not make breach tolerable to consumers. Indeed, for many consumers, the likelihood of collecting sucli damages is remote, because detection of defects is often difficult, ${ }^{10}$ and litigation expenses often make the pursuit of damages impractical. ${ }^{11}$

The pliglit of consumers ${ }^{12}$ illustrates serious flaws in the mechanism for collecting compensatory damages. To the extent that

- Perhaps the best-known presentation of this argument is in R. Posner, Economic ANalYsis of LAw 88-93 (2d ed. 1977). For other presentations of the same argument, see sources cited at note 28 infra. One might well question the importance of favoring efficient breach to the nation's well-being, because European nations have prospered without it. See Farnsworth, supra note 3 , at 1150-51.

7 The Second Restatement was completed at the fifty-sixth annual meeting of the American Law Institute in May 1979. The official text has not yet been published.

- Restatement (Second) of Contracts, Reporter's Note ch. 16, at 4-8 (Tent. Draft. No. 14, 1979).

- See, e.g., FTC, Rbport of thb Task Force on Appliance Warrantees and Service, reprinted in Consumerism: SkARch por the Consumer INTERest 259 (2d ed. 1971); L. Feldman, Consumer Protection: Problems \& Prospects 22-25 (1973); Nader, The Great American Gyp, in Consumarism: Search for the Consumer INTERest 43-58 (2d ed. 1971).

10 On the informational problems of consumers, see L. FELdman, supra note 9, at 22-25, 37-39; Birmingham, The Consumer as King: The Economics of Precarious Sovereignty, 20 Case W. Res. L. Rev. 354 (1969); Dohan, Cost Maximization and Buyer Dependence on Seller Provided Information, 10 J. Econ. Issues 430, 438-39, 447 (1976); Shaffer, On Reasonable Rules for Consumer Protection, in Economics of Consumer Protection 23 (L. Mather ed. 1971).

1 See Leff, Injury, Ignorance \& Spite-The Dynamics of Collective Coercion, 80 YalE L.J. 1, 8-18 (1970).

12 These enforcement problems are also present in the context of construction contracts. See notes 83-115 infra and accompanying text. For a discussion of the role of the general contractor, see J. SwBEt, Lbgal Aspects of Architecture, Enginebring aNd the ConstrucTION Process 241-46, 450-57 (2d ed. 1977). 
every prospective plaintiff is not fully compensated, even though "compensatory" damages are awarded in every litigated case, contracts are underenforced. ${ }^{13}$ Such underenforcement produces a number of economically undesirable results, including an excessive level of breach and excessive resort to self-help remedies.

This article develops this criticism of the strict-compensation model into a more rigorous economic analysis of contract damages. Part I sets out the basic economic concepts that are used in the analysis. Part II uses some basic quantitative models to explore the impact of compensatory damages on economic efficiency. These models demonstrate that compensatory damages do not produce economically optimum conduct, and that supercompensatory damages $^{14}$ can improve efficiency. Part III applies these models in the context of construction contracts and concludes that supercompensatory damages should be awarded for bad-faith breaches. ${ }^{15}$

\footnotetext{
13 Some writers believe that the underenforcement problem is severe. Professor Leff has contended that, "[u]nder the American law of contracts, after the other party has fully performed his obligations it is absolutely irrational for you fully to perform yours." Leff, supra note 11, at 5. See also Schwartz, The Case for Specific Performance, 89 Yale L.J. 271, 276 (1979).

${ }^{14}$ This article uses this term to describe any award of damages that exceeds the amount needed to put the plaintiff in the same position as full performance. Althougl supercompensatory damages have a penalty element, the mechanism for imposing sucls damages need not correspond to the traditional jury determmation of punitive damages. See generally D. DosBs, supra note 3, at 204-21.

18 The proper role of economic analysis in law is currently in great dispute. Efforts have been made, for example, to prove that the common law tends to produce economically efficient results. See, e.g., Goodman, An Economic Theory of the Evolution of the Common Law, 7 J. Legat STUd. 393 (1978); Landes \& Posner, Salvors, Finders, Good Samaritans and Other Rescuers: An Economic Study of Law and Altruism, 7 J. LegAL STUd. 83 (1978). A survey of the literature may leave the impression that many cases of validation simply stem from an ability to justify nearly any judicial decision by postulating appropriate transaction costs.
}

A strong commitment to "law and economics" is not a necessary premise to this article. One need not believe that economics provides insight into criminal law and the first amendment, see, e.g., R. PosNBR, supra note 6, at 536-51, however, to believe that economics helps in analyzing the law of commercial transactions. Nor is acceptance of economic efficiency as the main goal of law, see Leff, Economic Analysis of Law: Some Realism About Nominalism, 60 VA. L. Rev. 451 (1974), necessary to an acceptance of it as a reasonable goal in regulating commercial contracts. See Rogers, Book Review, 93 Harv. L. REv. 1039, 1048-49 (1980).

The clioice between damage standards depends upon an assessment of their relative costs. Because little or no empirical data exists concerning the relevant information, enforcement, and hargaining costs, this assessment must rely on experience and intuition. Although any conclusions must therefore be tentative, this does not counsel abandonment of the economic 


\section{Basic Economic Concepts ${ }^{16}$}

The economist's analytical starting point is the free market. The basic model of the market involves a large number of sellers competing to sell identical goods to a large number of buyers. ${ }^{17}$ This model, somewhat surprisingly, has some normative significance. In an important but limited sense, the results that are reached in this idealized model are indeed "ideal." With any given technology and distribution of wealth, the idealized market will produce an equilibrium state that could not be improved across-the-board. ${ }^{18}$ That is, some people could be made better off but only by making others worse off. Such an equilibrium state is called a Pareto optimum. Different Pareto-optimum states exist for different initial wealth

investigation, but merely suggests caution concerning the results. Certainly, given the state of the art, it would be a mistake to rely solely on economics in resolving these issues.

16 This section introduces the reader to the basic economic concepts used in this article. Obviously, a comprehensive treatment of basic microeconomics is impossible; the discussion merely attempts to define the basic terms and principles. This introductory discussion will of necessity ignore many subsidiary assumptions and qualifications. Of the additional assumptions, perhaps the most important are those of convexity and zero redistribution cost. See Polinsky, Economic Analysis as a Potentially Defective Product: A Buyer's Guide to Posner's Economic Analysis of Law, 87 HARv. L. REv. 1655, 1667-69, 1675-80 (1974). This article also ignores income effects and "second best" arguments. For detailed discussion of these additional complications, see M. Friedman, Price Theory: A Provisional Text 22-29, 47-54 (1976); Markovits, A Basic Structure for Microeconomic Policy Analysis in Our Worse-Than-Second-Best World: A Proposal and Related Critique of the Chicago Approach to the Study of Law and Economics, 1975 Wis. L. REv. 950, 967-95.

${ }^{17}$ A number of assumptions are made to simplify the model: that sales are instantaneous, that sellers do not have to search for buyers, that bargaining is costless, that everyone pursues his own self-interest, and that everyone knows what everyone else is doing. More technically, the assumptions are zero transaction costs, perfect information, see J. HIRSHLEIFER, Price Theory and Applications 198-201 (1976); Polinsky, supra note 16, at 1665-67, and complete rationality, see J. Henderson \& R. Quand, Microeconomic Theory: A MatheMatical Approach 8 (2d ed. 1971). For a discussion of the significance of these kinds of assumptions, see Friedman, The Methodology of Positive Economics, in Readings in Microeconomics 23 (2d ed. 1971); Nagel, Assumptions in Economic Theory, in Readings in Microeconomics, supra, at 48. Given these assumptions, several important conclusions follow. First, each seller will cease production when the profit from producing one additional good is zero, that is, when marginal revenue equals marginal cost. See M. Frizdman, supra note 16, at 116-17; J. HiRShLEIFER, supra, at 233-39. Furthermore, a price exists at which sellers are willing to sell precisely the quantity of goods that buyers wish to buy. See $i d$. at 22-23, 164-82. This is the "market clearing" price, toward which the market will tend to force buyers and sellers. See id. at 23-24. For a more extensive discussion, see J. HENDERson \& R. QUANDT, supra, at 132-51, 191-204.

${ }^{18}$ See J. HENDERson \& R. QUANDT, supra note 17, at 255-64; J. HirshleIFER, supra note 17, at 442-46; Polinsky, supra note 16, at 1667-69. 
distributions. Because none of these "optimum" states could be improved across-the-board, they could be ranked only if an objective method existed to evaluate the desirability of particular wealth distributions. The advantage of the Pareto criterion is that it allows some changes to be identified as improvements without assessing the relative value of money to different individuals. If one person's situation can be improved without causing a loss to anyone else, a clear social gain will occur, resulting in a "Pareto improvement" over the old. ${ }^{19}$ Because Pareto improvements are difficult to obtain, economists are sometimes content to look for efficiency gains, ${ }^{20}$ which occur when society's total wealth has been increased, although possibly at a cost of some wealth redistribution. Because it maximizes efficiency, the competitive market is generally the economist's preferred model when the conditions required for a viable market exist.

The primary strength of the free market is that the price mechanism provides an effective method of allocating resources. This mechanism only works correctly, however, if the prices of goods fully reflect the social costs and benefits of their production. Where the production of goods creates "externalities" that are not reflected in the price, ${ }^{21}$ a inisallocation occurs. ${ }^{22}$ Under ideal conditions, ${ }^{23}$ however, the market is able to reflect the cost of externalities. ${ }^{24}$

10 See J. HIRSHLEIPRR, supra note 17, at 438-42. For an alternative approach, see Markovits, supra note 16, at 984-90.

${ }^{20}$ See R. PosNer, supra note 6, at 10-12.

${ }^{21}$ See J. HIRSHLEIFER, supra note 17, at 449-53.

${ }^{22}$ See Williamson, Transaction-Cost Economics: The Governance of Contractual Relations, 22 J.L. \& EcoN. 233 (1979); Williamson, Wachter \& Harris, Understanding the Employment Relation: The Analysis of Idiosyncratic Exchange, 6 BeLL J. EcoN. 250 (1975). For example, if steel manufacture causes pollution that injures crops, then crop injury is a real cost of steel production. If steelmakers are not liable for this injury, however, the cost may not be reflected in their behavior-they will have "externalized" the cost.

is See note 17 supra.

24 This result has become known as the Coase Theorem. See J. HirshleIrer, supra note 17, at 451; R. PosNER, supra note 6, at 35-36, 184, 207 n.3; Polinsky, supra note 16, at 1669 71. The original statement of the Coase Theorem is found in Coase, The Problem of Social Cost, 3 J.L. \& EcoN. 1 (1960). The Coase Theorem has generated an extensive body of hterature. See, e.g., Dahlman, The Problem of Externality, 22 J.L. \& Econ. 141 (1979); Goldberg, Toward an Expanded Economic Theory of Contract, $10 \mathrm{~J}$. EcoN. Issues 45 (1976); Kelman, Consumption Theory, Production Theory, and Ideology in the Coase Theorem, 52 S. CAL. L. Rev. 669 (1979); Samuels, The Coase Theorem and the Study of Law and Economics, 14 NAT. RESOURCBS J. 1 (1974). 
II. Transaction Costs, Imperfect Information, and the Efficiency Effects of Contract Damages: Three Models of BREACH

Several methods exist for dealing with breach of a contract. When a breach becomes profitable for one party to a contract, the parties can negotiate an agreement before breach or they can litigate after breach. To protect itself against breach, each party may intensify its monitoring of the other side's performance. Alternatively, individuals can search for partners with a low propensity toward breach. These options all have costs, however, and create potential efficiency losses. This section considers the effects of these transaction costs in the the context of three simple models.

\section{A. Model I: Enforcement Costs and Efficient Damages}

Model I is based on a hypothetical Professor Posner used to present the efficiency argument for strict compensatory damages. ${ }^{2 s}$ The model presented here exposes the flaws in this argument and its dependence on questionable assumptions about transaction costs. Model I involves three variations on the basic situation of an outsider bidding for goods already subject to a sales contract. The variations involve subsidiary assumptions concerning damages and transaction costs. In Model IA, the subsidiary assumptions are zero transaction costs and the availability of compensatory damages. Model IA provides a convenient method of presenting the argument for compensatory damages and slowing its dependence on the absence of transaction costs. Model IB demonstrates the impact of litigation costs on efficiency. Besides changing the transaction-cost assumption, this model differs from Model IA in its use of a competitive market for standardized goods, rather than a negotiated sale of a unique good. Under Model IB, compensatory damages do not lead to efficient behavior. Model IC demonstrates

In the example of steel manufacture, see note 22 supra, farmers could pay the steel manufacturers to lower production. By effectively creating a market for pollution control, the price mechanism alters the steelmakers' behavior to reflect the impact on crop production. This internalization of pollution costs will only occur, however, if transaction costs do not prevent the establishment of a market for pollution control. For detailed discussion of the pollution problem and various solutions, see Calabresi \& Melamed, Property Rules, Liability Rules and Inalienability: One View of the Cathedral, 85 HARv. L. REv. 1089 (1972).

${ }^{25}$ R. POSNER, supra note 6, at 89-90. 
that supercompensatory damages can improve efficiency, assuming that both negotiation and litigation are costly. ${ }^{28}$

\section{Model IA: Zero Transaction Costs}

In Model IA, $B$ (a buyer) and $S$ (a seller) contract for the production of unique goods. Before the delivery date, $X$ (a third party) offers to buy the goods from $S$. Assuming zero transaction costs, compensatory damages clearly lead to efficient results. If the value of the goods to $X$ exceeds their monetary value to $B, X$ can efficiently offer $S$ a price in excess of the value to $B$. At this price, $S$ can breach, pay compensatory damages to $B$, and still make a profit. ${ }^{27} X$, who values them more highly, will have the goods, and $B$ will have been fully compensated. This result is a Pareto improvement over the situation that would have existed if the contract had heen performed. Similarly, if $B$ values the goods more highly than $X, B$ 's compensatory damages will exceed the price that $X$ is willing to pay, and $S$ will not breach. Compensatory damages again produce a Pareto-optimal result..28

The fundamental flaw in using such an argument to prove the

2t The conclusions drawn from Model I do not apply only to sale-of-goods contracts, but also to a much broader range of situations. Model I merely provides a convenient way of discussing any postcontract event that makes breach appear more profitable than performance.

${ }^{27}$ Arguably, to be fully compensated, an aggrieved buyer should receive as damages the amount in excess of the contract price that the third party paid for the good. See note 46 infra. Under conventional contract principles, however, the injured party receives only the value of full performance, and not the price he could have received for his right to rescind or assign the contract absent a breach. See R. Posner, supra note 6, at 88-90; Simon \& Novack, Limiting the Buyer's Market Damages to Lost Profits: A Challenge to the Enforceability of Market Contracts, 92 HaRv. L. Rzv. 1395 (1979). Nor is the aggrieved party entitled to damages arising from fluctuations in market price between the time of contract formation and the delivery date. See Jackson, "Anticipatory Repudiation" and the Temporal Element of Contract Law: An Economic Inquiry into Contract Damages in Cases of Prospective Nonperformance, 31 StaN. L. REv. 69, 75-77 (1978).

28 See E. Farnsworth, W. Young \& H. Jones, Casbs and Materials on Contracts 491 92 (2d ed. 1972); R. Posner, supra note 6, at 89-90; REstatement (Second) of Contracts, supra note 8, Introductory Note, 4-7; Barton, The Economic Basis of Damages for Breach of Contract, 1 J. Legal STud. 277, 287-91 (1972); Birmingham, supra note 5, at 284-86; Clarkson, Miller \& Muris, Liquidated Damages v. Penalties: Sense or Nonsense?, 1978 Wis. L. Rev. 351, 359-62; Goetz \& Scott, Liquidated Damages, Penalties and the Just Compensation Principle: Some Notes on an Enforcement Model and a Theory of Efficient Breach, 77 CoLUm. L. REv. 554, 558 n.19 (1977); Jackson, supra note 27, at 86 n.59. Several of these sources also consider the effect of transaction costs. See notes $41-48$ infra and accompanying text. 
efficiency of compensatory damages is that given zero transaction costs, any other sanction for breach will also produce a Pareto-optimal result. To take the most extreme case, suppose that breach of contract were a capital offense. $S$ would not be willing to breach even if $X$ offered to pay far more than the goods are worth to $B$. $X$ would still ultimately receive the goods, however, as $X$ would either pay $B$ to assign him the contract or buy the goods from $B$ after delivery. ${ }^{29}$ Absent transaction costs, no assignment of liability will prevent the parties from achieving this distribution of goods. This conclusion is simply a corollary of the more general Coase Theorem. ${ }^{30}$ Thus, the proposition that compensatory damages produce efficient results, assuming zero transaction costs, is true but vacuous. The proposition is not necessarily true, however, if transaction costs are positive, ${ }^{31}$ as will be shown in the next section.

\section{Model IB: Positive Enforcement Costs}

The next variant of Model I incorporates some of the major transaction costs involved in contract enforcement, ${ }^{32}$ such as attorneys' fees ${ }^{33}$ and foregone interest, ${ }^{34}$ neither of whiclı can normally

29 See Goetz \& Scott, supra note 28, at 568; Kronman, Specific Performance, 45 U. CHI. L. REv. 351, 353 n.12 (1978); Note, Liquidated Damages and Penalties Under the Uniform Commercial Code and the Common Law: An Economic Analysis of Contract Damages, 72 Nw. U.L. REv. 1055, 1078 (1978).

so See text accompanying note 24 supra.

${ }^{31}$ In addition to the effects of transaction costs discussed in this article, compensatory damages are also inefficient where two other kinds of costs are involved. First, if the parties engage in a costly search for partners both before and after breach, compensatory damages may result in inefficient levels of search or breach. See Diamond \& Maskin, An Equilibrium Analysis of Search and Breach of Contract, I: Steady States, 10 BeLl J. Econ. 282 (1979). Second, if the parties engage in costly reliance and are unable because of transaction costs to contract for efficient reliance levels, compensatory damages will lead to excessive reliance. See Shavell, Damage Measures for Breach of Contract 10 (unpublished draft of an article to appear in 11 BeLL J. EcoN. (1980)) (copy on file with the Virginia Law Review Association).

32 See generally Cheung, Transaction Costs, Risk Aversion, and the Choice of Contractual Arrangements, 12 J.L. \& EcoN. 23 (1969).

ss See Leff, supra note 11, at 8-18.

st Whetber prejudginent interest can be collected at all in the absence of a specific contractual provision generally depends on whetler the debt is considered liquidated. See $5 \mathrm{~A}$. Corrin, supra note $3, \S 1046$. A minority of jurisdictions allow interest on unliquidated claims. Id. \$ 1048, at 289. Even when available, however, tbe interest award will be unsatisfactory because compounding is not allowed, see id. $\S 1047$, and because interest is computed at the "legal" rate, see id. § 1046, at 280, which is now generally far below market interest rates. Compare N.Y. Crv. Prac. Law $\$ 5004$ (McKinney 1963) (the legal rate in New York as of April 10, 1980 was 6\%), with Wall St. J., April 10, 1980, at 6, col. 4 (prime rate 
be recovered as part of the damage award. Thus, an award of conventional compensatory damages will result in a net loss for the plaintiff. The following variant of Model I demonstrates the economic effects of these costs. For convenience, this model can be considered in two stages. In the original stage, transaction costs are zero. Numerous buyers and sellers enter into contracts for the future delivery of goods at price P. Breach results in compensatory damages. To simplify the model, assume that each seller can produce and sell only a single good ${ }^{35}$ and that each buyer purchases only a single good. At contract formation, both parties know of other potential buyers outside this market who may bid for the goods prior to dehvery. Under these initial conditions, the supply and demand curves are $Q=S(P)$ and $Q=D(P)$, respectively, with equilibrium at $\left(\mathrm{P}_{0}, \mathrm{Q}_{0}\right) \mathrm{s}^{96}$ This equilibrium under zero transaction costs represents the optimum level of trade. Assume that these initial conditions are changed so that the process of collecting compensatory damages, whether through settlement or litigation, costs each party L. The new supply and demand curves are $S^{\prime}(P)$ and $D^{\prime}(P)$.

Appendix A demonstrates that, given these assumptions, $S^{\prime}(P)$ $<\mathrm{S}(\mathrm{P})$, and $\mathrm{D}^{\prime}(\mathrm{P})<\mathrm{D}(\mathrm{P})$. In other words, the existence of transaction costs depresses both the supply and demand curves, as shown in Figure 1. At any value of $P$, either the supply or demand curve is now found somewhere in the hatched area of Figure 1. Consequently, the equilibrium point $Q^{\prime}$ must be somewhere in this area ${ }^{37}$ and is clearly lower than $Q$. Thus, litigation and settlement costs decrease the commitment of resources to the production of these goods below the optimum level.

\footnotetext{
was $20 \%$ ).

ss Under this assumption, marginal and average costs are equal.

s6 Here, as elsewhere, all functions are assumed to be continuous.

37 This assumes that an equilibrium still exists. The effect of litigation costs conceivably could be so severe that sellers would be willing to enter only at prices in excess of those any buyer was willing to pay. $S^{\prime}(P)$ and $D^{\prime}(P)$ then no longer would cross, and no equilibrium would exist; indeed, the market for these goods would disappear.
} 


\section{FIGURE 1}

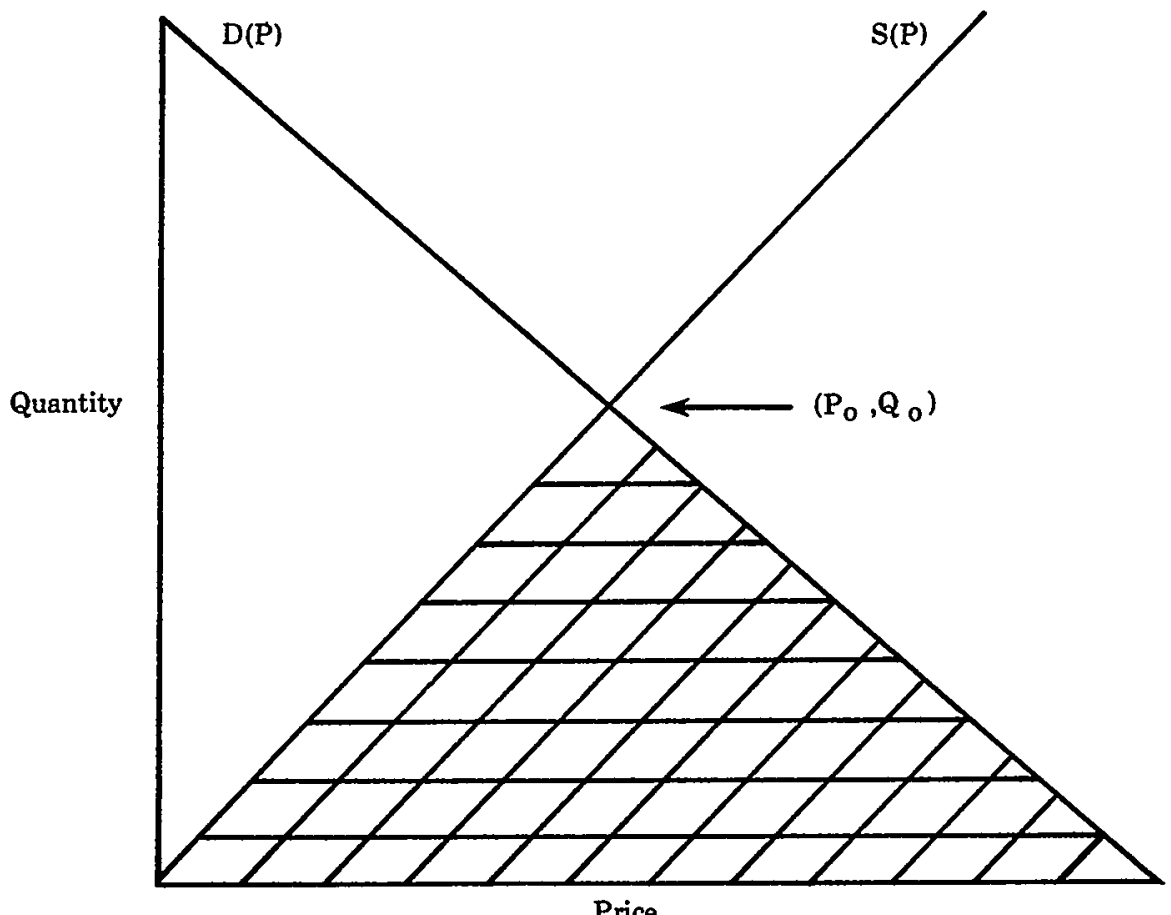

\section{Model IC: Negotiation Versus Litigation}

Model IB demonstrated that litigation costs will result in a distortion of resource allocation..$^{38}$ The question remains whether supercompensatory dainages produce better results. If supercompensatory dainages are awarded, the outside buyers in Model IB will no longer be willing to deal witl the sellers. No seller will breach lis contract unless lie receives at least $P+D_{c}+D_{p}$ where $D_{c}$

ss Litigation expenses also result in a wealth transfer from producers and consumers to lawyers that benefits only one segment of society. Hartzler argues that litigation costs also benefit litigants because they receive a valuable service. See Hartzler, The Business and Economic Functions of the Law of Contract Damages, 6 AM. Bus. L.J. 387, 403 (1968). Presumably, the same argument would also show that medical expenses should not be recovered by tort victims because they too have received a valuable service. Hartzler also argues that failure to compensate for litigation costs has no economically harmful effects. Id. at 404. As the discussion in the tert demonstrates, this argument is also unfounded. See text accompanying notes $40-45$ infra. 
is the seller's compensatory damage payment and $D_{p}$ is the punitive damage payment. In contrast, the lowest price at which a buyer will be willing to resell the goods or assign his contract is $P+D_{c}$, because this is the value of the goods to him. ${ }^{38}$ Clearly, the outside buyer will prefer to deal with the contract buyer, so as to avoid having to finance the seller's payment of punitive damages. The question then is whether breach is more efficient than direct dealing between the contract buyer and a third party.

To investigate this problem, consider the situation of a single buyer $B$ and seller $S$. An outsider $X$, who values the goods more highly than $B$, intends to bid for the goods. There are three possible outcomes:

(a) Performance. $S$ performs his contract with $B$, and $B$ uses the goods. This outcome is undesirable, because $X$ values the goods more highly than $B$.

(b) Breach. $S$ breaches his contract with $B$ and sells to $X$. There are two transaction costs: $N_{1}$ (the costs of the $X-S$ negotiation) and L (the costs of hitigation or settlement between $S$ and $B$ ).

(c) Direct Dealing. $S$ refuses to breach his contract with $B$, but $X$ pays $B$ to assign his contract to $X$ (or $B$ resells to $X$ ). There are again two transaction costs: $C$ ( $X$ 's costs in contacting $B$ ) and $\mathrm{N}_{2}$ (the cost of the $X-B$ negotiation).

Outcome (a) is clearly the least desirable, assuming that the transaction costs do not outweigh the benefits of reallocating the goods to X. It also appears that outcome (c), which results from supercompensatory damages, is probably more desirable than outcome (b), which is produced under a conventional compensatory scheme. ${ }^{10}$

There are two reasons for preferring outcome (c). First, it is likely that outcome (c) represents an efficiency gain over outcome (b). The efficiency question depends on whether the transaction costs of breach, $\mathrm{N}_{1}+\mathrm{L}$, exceed the transaction costs of direct dealing, $\mathrm{C}+\mathrm{N}_{2} . X^{\prime}$ 's cost $\mathrm{N}_{1}$ of negotiating with $S$ and his cost $\mathrm{N}_{2}$ of negotiating with $B$ can be expected to be roughly the same. On

30 If search or negotiating costs make it impractical for an $X$ to deal with more than one $B$, that $B$ may be able to negotiate a price in excess of $P+D_{c}$ but less than $P+D_{c}+D_{p}$. ( $B$ cannot extract more than the latter figure, because $S$ would be willing to breach for any greater price.)

10 For a similar argument concerning specific performance remedies, see Schwartz, supra note 13 , at $284-91$. 
the other hand, the litigation cost $\mathrm{L}$ can be expected to be fairly large, ${ }^{41}$ while $\mathrm{C}$, the cost of a phone call to $S$ to learn his buyer's name, can be expected to be quite low. ${ }^{42}$ So in general, it can be assumed that $\mathrm{L}+\mathrm{N}_{1}>\mathrm{C}+\mathrm{N}_{2}$. Hence, outcome (c) is more efficient.. ${ }^{+3}$ Several additional considerations support this analysis of efficiency. In outcome (b), $S$ must decide whether the gain to $X$ would outweigh the loss to $B$. $B$, however, is in a much better position than either $X$ or $S$ to know his own probable loss. ${ }^{44}$ Holding $S$ to the contract lets $B$ make this decision by choosing whether to assign his contract or resell the goods. Furthermore, $X$ and $S$ may make an inefficient choice between breach and performance, because they can shift part of the litigation cost to $B . .^{45}$

The second reason for preferring outcome (c) is more fundamental. Even if transaction costs were lower for breach than for direct dealing, making outcome (b) preferable on efficiency grounds, outcome (b) is still not a Pareto improvement over outcome (c), because a redistributive effect has also occurred. In outcome (c), $B$ gets part of the benefit of the social gain created by reallocating the goods to $X$. In outcome (b), the gain goes entirely to $X$ and $S$.

4 This cost is entirely overlooked in the Posner, Farnsworth, Birmingham and Second Restatement discussions cited in note 28 supra. Clarkson, Miller \& Muris, supra note 28, at 362-63 n.34, make the assumption that the cost will be very small because the breaching party will "simply send [the other party] the amount the law requires as damages."

12 In this model, the cost of the phone call is probably the only transaction cost, but $X$ may also have to pay $S$ a fee for the information. This fee may allow $S$ to capture soine of the efficiency gaim created by reallocating the goods to $X$ and represents a simple wealth transfer, not an efficiency loss. Negotiation over this fee unay produce an additional transaction cost.

There are two additional complications. First, the litigation cost will be much lower if the damages are readily calculable--for example, when $B$ can easily cover in the market. Thus, the analysis in the text may be less decisive when complete substitutes are readily available in the market. See Scliwartz, supra note 13, at 285-86, 288. Second, supercompensatory damages may decrease the transaction costs of direct dealing by encouraging the growth of new institutional structures to facilitate such trade.

4s A more complete discussion of this point in the UCC context can be foumd in Schiro, supra note 2, at 1731-49. Schiro does not discuss quality-related breaches like those involved in Model II.

4 See id. at 1742-43.

43 See text accompanying notes 33-34 supra. Total cost caused by breach will be $L+N_{1}$, but assuming symmetry, only (L/2) $+N_{1}$ will be incurred by $B$ and $X$. Hence, they may breach when their added profits are between $L+N_{1}$ and $(L / 2)+N_{1}$. When breach is not caused by a bid from a third party, externalization of litigation costs will be restricted because $S$ 's litigation costs will be tied, at least loosely, to $B$ 's. Externalities may still be a problem if hitigation costs are not distributed symmetrically between $S$ and $B$. 
Thus, shifting from supercompensatory to compensatory damages redistributes wealth from $B$ to $X$ and $S$. Because interpersonal comparisons of utility are impossible, this change cannot be called an improvement, even if efficiency has been increased..$^{48}$ Moreover, this redistribution of income can hardly be justified on moral grounds, because $B$ is the only party who does not participate in $S$ 's breach of his promise. ${ }^{12}$

Model I thus demonstrates that while compensatory damages do produce an optimum result where there are no transaction costs, the same result can be achieved with other measures of damages. Moreover, where significant transaction costs are involved, compensatory damages fail to produce an optimum result. Supercompensatory damages can minimize this inefficiency by causing a shift from breach to contract assignment as a means of resource reallocation. ${ }^{48}$

\section{B. Model II: The Impact of Imperfect Detection}

The previous section considered costs deriving from the disputeresolution mechanism itself. Although the effects of these costs are significant, they could conceivably be altered from within the legal system by reducing litigation costs or by shifting the cost to the state or to the losing party. ${ }^{40}$ In contrast, the costs considered in

16 The redistributive effect can also be seen as a failure of full compensation. Arguably, $B$ should recover $S$ 's profits, hecause these profits would have gone to $B$ if $S$ had not breached, for $B$ could then have profitably resold or assigned to $X$. See Simon \& Novack, supra note 27, at 1437 (arguing for "disgorgement of the unfair market advantage" gained by the breacher). See also Landa, An Exchange Economy With Legally Binding Contract: A Public Choice Approach, 10 J. Econ. Issuzs 905, 912-13 (1976).

17 Splitting the benefits from breach hetween $S$ and $B$ is also more appealing than allocating these benefits entirely to $S$. Moreover, no apparent efficiency loss would result. See Birmingham, Damage Measures and Economic Rationality: The Geometry of Contract Law, 1969 Duke L.J. 49, 68-69; Goetz \& Scott, supra note 28, at 567.

is Given the problems of the argument for compensatory damages, one might wonder how the strict compensation principle hecame so firmly established. Perhaps, the courts were reflecting prevailing theories of Social Darwinism, rewarding the breaching party for being more "efficient," or at least more ruthless, than the victim of breach. See Note, supra note 29, at 1081-82. See generally G. Gimore, The Ages of Amzrican Law 48-56 (1977); G. Grmore, The Death of Contract 14-17 (1974).

15 The suggestion bas been made that legal rules causing systematic undercompensation should be directly modified rather than being used to justify changes in damage rules. See Jackson, supra note 27, at 86 n.59. Direct modification of these "procedural" rules, however, could bave unintended side effects. For example, awarding attorneys' fees to plaintiffs could cause excessive investment in litigation. 
this section originate outside the legal system. As such, the problem is in a sense more serious, because the legal system cannot resolve the problem through procedural changes. Rather, the problem is inherent in the transactions that the law must regulate.

Although commentators frequently assume that contract breaches can be instantly and costlessly detected, ${ }^{50}$ such detection is often costly or even impossible. The consumer who contracts to have a car repaired or a house built is often unable to determine whether the job has been properly performed. He may require the services of an expert to make sure the work has been done competently. ${ }^{51}$ Even when the final product clearly deviates from the contract specifications, the seller may offer legitimate excuses; for example, a defect may have arisen while goods were in transit, after the risk of loss has passed to the buyer. ${ }^{52}$ These detection costs are external to the legal system but cannot be ignored in considering the economic impact of contract damages. ${ }^{\text {ss }}$

Model II will be used to investigate the impact of these detection costs. Assume a market with many buyers and sellers and with goods that come in two varieties, nondefective and defective. Nondefective goods cost sellers $C_{G}$ to produce and are worth $V_{G}$ to buyers. Defective goods cost sellers $C_{D}$ to produce and are worth $V_{D}$ to buyers. ${ }^{54} \mathrm{X}$ is the percentage of nondefective goods. Assume further that production of nondefective goods is economically rational, i.e., that $\mathrm{V}_{\mathrm{G}}>\mathrm{V}_{\mathrm{D}}+\left(\mathrm{C}_{\mathrm{G}}-\mathrm{C}_{\mathrm{D}}\right)$. $\mathrm{Y}$ is the probability that if a defect exists the buyer will discover it. Two variants of this model

so See R. PosNER, supra note 6, at 468. For example, a recent article concerning breach of sales contracts fails to include inspection costs in discussing the relevant allocative and distributive costs. See Priest, Breach and Remedy for the Tender of Nonconforming Goods Under the Uniform Commercial Code: An Economic Approach, 91 HaRv. L. REv. 960, 96367 (1978).

31 On the architect's role, see J. SwEET, supra note 12, at 99-105.

ss See U.C.C. \& 2-509(1)(a).

ss Although the effect of these costs on damage rules has received little attention, commentators have examined their effect on contracting. See Alchian \& Demsetz, Production, Information Costs, and Economic Organization, 62 AM. Econ. Rev. 777 (1972); Williamson, supra note 22; Williamson, Wachter \& Harris, supra note 22. See generally Kronman, Mistake, Disclosure, Information, and the Law of Contracts, 7 J. LEGAL STUD. 1 (1978).

ot The constant-cost assumption not only simplifies matters by allowing marginal cost to be equated with actual cost, but also has strong empirical support. See Roth, Empirical Cost Curves and the Production-Theoretic Short Run: A Reconciliation, Q. REv. Econ. \& Bus., Autumn 1979, at 35. In the model used in the text, "cost" includes return on capital and on "entrepreneurial capacity." See M. Friedman, supra note 16, at 90, 105-07. 
will be considered. In Model IIA, Y will be constant. In Model IIB, $\mathrm{Y}$ will be variable, and increases in $\mathrm{Y}$ will be costly. Damages are set at D. ${ }^{.5}$

\section{Model IIA: Constant $Y$ \\ a. Case 1: $Y=0$}

To see the economic impact of imperfect detection, it is helpful to begin with the extreme case of $\mathrm{Y}=0$. Suppose that a repair can be performed in two ways, $A$ and $B$. $A$ is cheaper for the repairman, but is less permanent. Indeed, the expense saved by the repairman is less than the loss to consumers, so that consumers would gladly pay the extra cost for repair $B$. Unfortunately, consumers are unaware that repair $A$ exists; thus, they do not know that the repairman might cheat. Even if they were aware of this possibility, they would be unable to detect the improper repair, because $\mathrm{Y}=\mathrm{O}$. For purposes of this example, the uniform cost and value assumptions of Model II can be relaxed. Instead, assume that under conditions of perfect knowledge, $A$ and $B$ would trade with normal supply and demand curves.

Figure 2 shows the resulting situation..$^{56}$ The curves labeled Supply $B$ and Demand B show the quantity of repair $B$ that sellers would be willing to provide and that buyers would be willing to buy at any given price. Given perfect information, and therefore no opportunity for cheating, equilibrium would be at $\left(P_{4}, Q_{2}\right)$. Because repair $A$ is cheaper than repair $B$, sellers would be willing to provide more of repair $A$ at any given price, so the curve Supply $A$ is higher than the curve Supply B. Similarly, because consumers value repair $B$ more highly than repair $A$, they would buy more of $B$ at any given price; thus, curve Demand $B$ is above curve Demand $A$. Given perfect information, the equilibrium for repair $A$ would be at $\left(P_{1}, Q_{3}\right)$.

\footnotetext{
ss The text does not address two subsidiary assumptions. First, "defects" are assumed to breach the contract of sale. Second, price is assumed to be fixed. See Appendix B. Allowing price to vary can be even more disruptive, because sellers will attempt to exploit buyers' tendency to use price as a proxy for quality. When price and quality are both allowed to vary, equilibrium may disappear entirely. See Rothschild \& Stiglitz, Equilibrium in Competitive Insurance Markets: An Essay on the Economics of Imperfect Information, 90 Q.J. EcoN. 629, 637 (1976).

so Linear supply and demand curves are used for simplicity, but do not affect the results.
} 


\section{FIGURE 2}

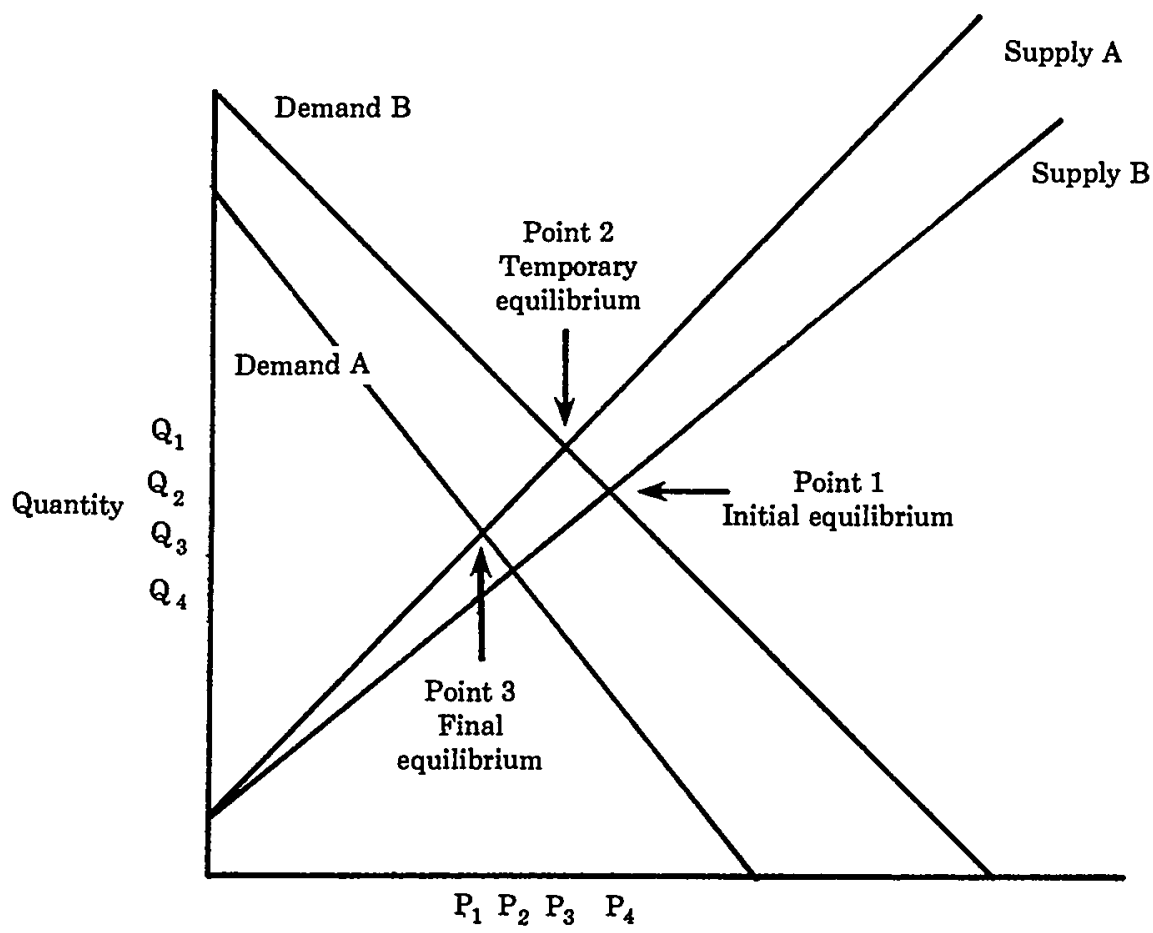

Price

Before sellers discover the possibility of cheating, equilibrium will be at $\left(\mathrm{P}_{4}, \mathrm{Q}_{2}\right)$. When sellers discover repair $A$, they will all switch to it, because it is cheaper; consumers, not knowing the difference in the two repairs, will pay the same price. Competition among sellers, who now have lower costs, will gradually drive down prices. The new equilibrium will be at point $2,\left(\mathrm{P}_{3}, \mathrm{Q}_{1}\right)$. Eventually, consumers will learn about the existence of repair $A$ and will switch to demand curve $A$. The result will be a final equilibrium at $\left(P_{1}, Q_{3}\right)$. Thus, the introduction of cheating will eventually result in a change from trade in repair $A$ to trade in repair $B$. This is an inefficient result. By hypothesis, the consumers' loss in value exceeds the cost saved by the sellers in switching to the inferior repair. Consumers would willingly pay sellers enough to move from point 3 to point 1 . Unfortunately, they are unable to do so because 
they lack any means of enforcing the bargain. ${ }^{67}$ This result cannot be changed by awarding additional damages, because buyers cannot detect breach.

\section{b. Case 2: $O<Y<1$.}

We now consider the case of fixed but partially effective detection. Returning to the assumption of uniform cost and value, the seller's expected profit can be expressed as the sum of the profits for defective and nondefective goods:

$$
\mathrm{Ex}(\mathrm{S})=\mathrm{X}\left(\mathrm{P}-\mathrm{C}_{\mathrm{G}}\right)+(1-\mathrm{X}) \cdot\left(\mathrm{P}-\mathrm{C}_{\mathrm{D}}-\mathrm{Y} \cdot \mathrm{D}\right)
$$

$\mathrm{Ex}(\mathrm{S})$ is a linear function of $\mathrm{X}$ with slope $\mathrm{YD}+\mathrm{C}_{\mathrm{D}}-\mathrm{C}_{\mathrm{G}}$. If this slope is positive, sellers will maximize their profits at $\mathrm{X}=1$; if the slope is negative, profits will be maximized at $X=0$. To ensure compliance, $D$ must be chosen so that $Y D+C_{D}-C_{G}>0$. As $Y$ decreases, $D$ must be increased to obtain compliance. ${ }^{\mathrm{BS}}$ Thus, depending on the size of $Y$, damages in excess of the compensatory level $\left(V_{G}-V_{D}\right)$ may well be necessary. ${ }^{69}$

A numerical example may be helpful. A certain repair can be performed in two ways, $A$ and $B$. Repair $A$ is worth $\$ 100$ to consumers; repair $B$ is worth only $\$ 80$. Each consumer has only a $10 \%$ probability of detecting the difference between the two repairs. Repair $A$ costs dealers $\$ 90$, while repair $B$ costs $\$ 80 .^{\circ 0}$ Under current market conditions, consumers enter into contracts for repair $A$ at $\$ 95$ and are entitled to compensatory damages. A dealer who always performs repair $B$ will earn $\$ 15$ on each sale, less a $10 \%$ chance of a $\$ 20$ damage payment to the consumer. Obviously, dealers will always perform repair $B$. As a result, consumers as a group receive only $80 \%$ of what they have bargained for, despite the availability of compensatory damages. If consumers discover this situation, they will contract for repair $B$, rather than $A$, and the market for $A$ will disappear. If, instead of awarding disappointed consumers compensatory damages of $\$ 20$, supercompensatory dam-

\footnotetext{
67 For an example of a similar effect, see Akerlof, The Market for "Lemons": Quality Uncertainty and the Market Mechanism, 84 Q.J. EcoN. 488 (1970).

ss To obtain compliance, $D$ must exceed $\left(C_{G}-C_{D}\right) / Y$. See generally $R$. Posner, supra note 6 , at 164-72.

s* Supercompensatory damages will be needed if $\left(C_{G}-C_{D}\right) /\left(V_{G}-V_{D}\right)>Y$.

-Cost" is used liere in tle everyday sense, excluding return on capital.
} 
ages of $\$ 200$ are awarded, ${ }^{\theta 1}$ the incentive for breach disappears. With supercompensatory damages, the $\$ 15$ profit from breach is more than offset by the $10 \%$ chance of a $\$ 200$ damage award.

This example also demonstrates that supercompensatory damages do not necessarily confer a windfall on successful plaintiffs. Suppose that some dealers continue to provide only defective repairs despite the adoption of supercompensatory dainages. Their customers continue to receive a service supposedly worth $\$ 100$, but actually worth only $\$ 80$ because it is defective. Although this is a $\$ 20$ loss, the customer also gets a chance of recovering $\$ 200$ if he is one of the $10 \%$ who are fortunate enough to detect the breach. This is equivalent to a lottery ticket representing a $10 \%$ chance at a $\$ 200$ prize. As the expected value of such a lottery ticket is $\$ 20$, the consumer in effect contracts for a service worth $\$ 100$, but receives a service worth $\$ 80$ plus a lottery ticket worth $\$ 20$. Clearly, no windfall exists even during the interim period. ${ }^{62}$

This variant of Model II demonstrates several propositions. First, inadequate detection may cause the collapse of the market for nondefective goods, because sellers have incentive to cheat if buyers receive only compensatory damages. Second, the use of supercompensatory damages can prevent this market collapse. Third, supercompensatory damages need not result in windfalls to plaintiffs.

\section{Model IIB: Variable, Costly Detection}

In reality, the level of detection is probably not fixed but instead hmited by cost. For a more realistic determination of the effects of imperfect detection, Model II can be modified by assuming that detection is costly. To have a probability $\mathrm{Y}$ of detecting a defect, buyers must spend $C(Y)$. Assume that $C(Y)$ has a continuous derivative $C^{\prime}(X)$ and a second derivative $C^{\prime \prime}(X)$, with $C^{\prime}(X)>0$, $\mathrm{C}^{\prime \prime}(\mathrm{X})>0$, so that marginal cost is always greater than zero and increases as the probability of detection approaches one hundred percent. When a buyer detects a defect, he receives a damage pay-

\footnotetext{
or Any measure of damages that exceeds the difference in the cost of the two repairs divided by the probability of detection, $\$ 150$ in the example, should deter dealers from cheating.

${ }^{62}$ See generally M. Friedman, supra note 16, at 262-78 (discussing risk and wealth distribution).
} 
ment $D$ from the seller. The price of the goods is $P{ }^{63}$ To compare equilibria, ${ }^{64}$ assume that an equilibrium exists with compensatory damages.

The expected value obtained by a $B$ is:

(1) $\operatorname{Ex}(B)=X\left(V_{G}-P\right)+(1-X) \cdot(1-Y) \cdot\left(V_{D}-P\right)+(1-X) Y\left(V_{D}-P+D\right)-C(Y)$.

Equation (1) is obtained by adding the expected values for nondefective goods, undetected defective goods, and detected defective goods, and then subtracting detection costs. Similarly,

(2) $E x(S)=X\left(P-C_{G}\right)+(1-X) \cdot\left(-Y \cdot D+P-C_{D}\right)$

If the first derivatives equal 0 , the following equations result at equilibrium:

(3) $\frac{\partial E_{X}(B)}{\partial Y}=-(1-X) \cdot\left(V_{D}-P\right)+(1-X) \cdot\left(V_{D}-P+D\right)-C^{\prime}(Y)=D(1-X)-C^{\prime}(Y)=0$

(4) $\frac{\partial E_{X}(\mathrm{~S})}{\partial \mathrm{X}}=\mathrm{P}-\mathrm{C}_{\mathrm{G}}+\mathrm{YD}-\mathrm{P}+\mathrm{C}_{\mathrm{D}}=\mathrm{C}_{\mathrm{D}}-\mathrm{C}_{\mathrm{G}}+\mathrm{YD}=0$

Solving these equations, the following equilibrium values ${ }^{65}$ are obtained for $\mathrm{X}^{*}$ and $\mathrm{Y}^{*}$ :

(5) $\mathrm{X}^{*}=1-\mathrm{C}^{*}\left(\mathrm{Y}^{*}\right) / \mathrm{D}$

(6) $\mathrm{Y}^{*}=\left(\mathrm{C}_{\mathrm{G}} \cdot \mathrm{C}_{\mathrm{D}}\right) / \mathrm{D}$

The first point of interest is the level of compliance under compensatory damages, $D=V_{G}-V_{D}$. With this value of $D$, the fol-

es On the fixed price assumption, see note 55 supra and Appendix B.

c The relevant mathematical techniques are summarized in J. HENDERSON \& R. QUANDT, supra note 17 , at $388-407$.

es To confirm that this is an equilibrium, it is necessary to show that neither party has any incentive to shift from this position. $B$ will not change $\mathrm{Y}$, because at $\mathrm{X}=\mathrm{X}^{*}, \partial \mathrm{Ex}(\mathrm{B})$ $=0$ and $\frac{\partial^{2} \mathrm{Ex}(\mathrm{B})}{\partial \mathrm{Y}^{2}}=-\mathrm{C}^{\prime \prime}(\mathrm{Y})<0$; thus, $\mathrm{Ex}(\mathrm{B})$ is maximized at $\mathrm{Y}^{*}$, given $\mathrm{X}=\mathrm{X}^{*}$. Given $\mathrm{Y}=\mathrm{Y}^{*}$, as shown in equation B1 in Appendix B, $\mathrm{Ex}(\mathrm{S})$ is constant; thus, there is no incentive for $S$ to vary $\mathrm{X}$. Furthermore, if $S$ did reduce $\mathrm{X}$, the $B$ 's would respond by increasing $\mathrm{Y}$. Because $\mathrm{Ex}(B)$ is maximized (given $X$ ) when $C^{\prime}(Y)=D(1-X)$, decreasing $X$ increases the requisite $C^{\prime}(Y)$ and thereby $Y$. Because $Y>Y^{*}$, equation (4) shows that $\partial \operatorname{Ex}(S)>0$; thus, $\overrightarrow{\mathrm{aX}}$

the $S$ 's have an incentive to increase $\mathrm{X}$ to $\mathrm{X}^{*}$. Similarly, if the $S^{\prime} \mathrm{s}$ increase $\mathrm{X}$ beyond $\mathrm{X}^{*}$, the $B$ 's will decrease $\mathrm{Y}$, thereby creating an incentive for the $S$ 's to decrease $\mathrm{X}$ to $\mathrm{X}^{*}$. 
lowing equilibrium values are obtained:

(7) $\mathrm{X}^{*}=1-\mathrm{C} \frac{\mathrm{C}\left[\frac{\left(\mathrm{C}_{G}-\mathrm{C}_{\mathrm{D}}\right)}{\left(\mathrm{V}_{G}-\mathrm{V}_{D}\right)}\right]}{\mathrm{V}_{G}-V_{D}}$

(8) $\mathrm{Y}^{*}=\left(\mathrm{C}_{\mathrm{G}}-\mathrm{C}_{\mathrm{D}}\right) /\left(\mathrm{V}_{\mathrm{G}}-\mathrm{V}_{\mathrm{D}}\right)$.

Because $C^{\prime}(X)>0, X^{*}<1$, sellers will always cheat to some extent. Moreover, with $\mathrm{Y}^{*}>0$, buyers will always use resources to inspect for defects. As both the level of breach and the level of detection costs represent inefficient uses of resources, compensatory damages obviously do not produce optimum results.

The next question is the effect of increasing damages. From equation (6), $\mathrm{Y}^{*}$ is a monotonically decreasing function of $\mathrm{D}$, and approaches $\mathrm{O}$ as $\mathrm{D}$ increases. As $\mathrm{Y}^{*}$ decreases, $\mathrm{C}^{\prime}\left(\mathrm{Y}^{*}\right)$ decreases, because $\mathrm{C}^{\prime \prime}\left(\mathrm{Y}^{*}\right)>0$. Hence, if $\mathrm{D}_{1}>\mathrm{D}_{2}$, then $\mathrm{C}^{\prime}\left(\mathrm{Y}^{*}\left(\mathrm{D}_{1}\right)\right)$ $<\mathrm{C}^{\prime}\left(\mathrm{Y}^{*}\left(\mathrm{D}_{2}\right)\right)$, and:

$$
\text { (9) } \begin{aligned}
\mathrm{X}^{*}\left(\mathrm{D}_{1}\right) & =1-\frac{\left(\mathrm{C}^{\prime}\left(\mathrm{Y}^{*}\left(\mathrm{D}_{1}\right)\right)\right)}{\mathrm{D}_{1}} \\
& \left.>1-\frac{\left(\mathrm{C}^{\prime}\left(\mathrm{Y}^{*}\left(\mathrm{D}_{2}\right)\right)\right.}{\mathrm{D}_{1}}\right) \\
& \left.>1 \cdot \frac{\left(\mathrm{C}^{\prime}\left(\mathrm{Y}^{*}\left(\mathrm{D}_{2}\right)\right)\right.}{\mathrm{D}_{2}}\right)=\mathrm{X}^{*}\left(\mathrm{D}_{2}\right)
\end{aligned}
$$

Thus, $\mathrm{X}^{*}$ increases as $\mathrm{D}$ increases. From equation (5), $\mathrm{X}^{*}$ approaches one as $\mathrm{D}$ increases. Therefore, increasing damages will progressively remove the two sources of inefficiency: cheating by sellers and detection costs incurred by buyers. ${ }^{68}$ Appendix $B$ shows

so The analysis becomes more complicated if risk aversion is considered. It can be shown that risk aversion by the buyer does not affect the results. If the buyer's utility is expressed as $\operatorname{Ex}(B)-R(X, Y, D)$, where $R$ measures loss of utility due to risk, then several additional 
that, if $D_{1}>D_{2}$, equilibrium at $D_{1}$ is a Pareto improvement over equilibrium at $D_{2}$. Efficiency thus can always be increased by increasing damages; complete efficiency would apparently require infinitely high punitive damages.

This result may seem puzzling. One might expect that witl sufficiently high damages, sellers would be completely deterred from breach. While the deterrent effect of damages obviously does increase with higher damages, the incentive for buyers to engage in detection decreases as the level of breach decreases. The decreased level of detection undermines the deterrent effect of increased damages by decreasing the probability of being caught. As a result, the level of breacl declines as damages increase, but never reaclies zero. $^{.82}$

One might also expect that with very ligh punitive damages, the damages themselves could be so valuable to buyers as to cause a distortion in demand, so that buyers would be purchasing goods that they did not need to get potential punitive damage claims. ${ }^{68}$ Suclı a distortion will not occur, lowever, because, as shown in Ap-

assumptions about $\mathrm{R}$ are necessary: namely, that $\mathrm{R}_{\mathrm{Y}}<0 ; \mathrm{R}_{\mathrm{YD}}<0 ; \mathrm{R}_{\mathrm{YY}}>0$; and $\mathrm{R}_{\mathrm{YX}}>0$. These assumptions follow from the plausible hypotheses that larger losses from defective goods increase risk and larger damage recoveries or increased proportions of nondefective goods decrease risk. Given these assumptions, $Y^{*}$ is unaffected because it is found by optimizing Ex(S). To determine the equilibrium value of $\mathrm{X}, \overline{\mathrm{X}}$ must be found such that

$$
\frac{\partial U(B)}{\partial Y}=0 \text { for } X=\bar{X}
$$

This partial derivative is negative at $X=1$ and positive at $X=X^{*}$. Hence, by continuity, a suitable $\bar{X}$ exists, and $\bar{X}$ can be shown to be unique. Using the assumptions about the risk function $R$, a proof along the lines of that in the text demonstrates that if $D_{1}>D_{2}$, then $\bar{X}\left(D_{1}\right)>\bar{X}\left(D_{2}\right)$, and as in the text, $Y^{*}$ decreases as $D$ increases. Hence, it will still be true that increasing damages improves efficiency.

On the other hand, if sellers are risk averse, equilibrium will generally no longer exist, because the equilibrium value of $\mathrm{X}$ will have to satisfy two independent relationships: $X^{\prime}=\frac{1-C^{\prime}(\bar{Y})}{D}$ and $C_{D}-C_{g}+Y D=r_{x}\left(X^{\prime}, \bar{Y}, D\right)$, where $X^{\prime}$ and $\bar{Y}$ are the equilibrium values and $r$ is the seller's risk function. In general, there is no reason to expect such an X' to exist. Risk aversion will probably make the parties more responsive to each other's behavior and thus improve efficiency under a dynamic analysis.

${ }^{67}$ Risk aversion by sellers, however, might force the breach level to zero once $D$ is sufficiently great. 06.

4s An effect of this kind is described in Diamond \& Maskin, supra note 31, at 294-99, 302- 
pendix $B,(P+\operatorname{Ex}(B))$ is a monotonically increasing function of $D$. Remembering that $\mathrm{X}^{*}(\mathrm{D})$ approaches one and $\mathrm{Y}^{*}(\mathrm{D})$ approaches zero, it is evident from equation (1) that

$$
\text { (10) } \mathrm{P}+\operatorname{ExB}(\mathrm{D})<\lim _{\mathrm{D} \rightarrow \infty} \operatorname{ExB}(\mathrm{D})+\mathrm{P}=\mathrm{V}_{\mathrm{i}}-\mathrm{P}+\mathrm{P}=\mathrm{V}_{\mathrm{G}}
$$

This equation demonstrates that, even with high punitive damage awards, buyers do not receive a windfall because their expected return is less than the value of nondefective goods.

Thus, the results under this model are the same as those under the simpler Model IIA. Compensatory damages will not assure an optimum level of performance, but increasing damages can improve the situation. The impact of hitigation costs on contract enforcement produced the same results in Model $\mathrm{I}^{69}$ Together these models strongly point to the conclusion that compensatory damages are inadequate to ensure efficient contracting and breach behavior.

\section{Model III: Precontracting Information Costs}

The discussion thus far has established that compensatory damages provide an madequate enforcement mechanism. The more difficult question is whether an increased level of damages is the appropriate method of dealing with the problem. In the previous models, supercompensatory damages have shown desirable effects. In the real world, however, supercompensatory damages can lead to two problems. First, such damages may be excessive or unwarranted because of mistakes about the economics of the underlying transaction. Second, increased damages may cause more litigation, particularly frivolous hitigation, which is costly for both the parties and society. ${ }^{70}$

These potential problems can support a reasonable argument that improved legal enforcement mechanisms are undesirable. After all, despite the present unavailability of adequate legal remedies, people still make contracts and generally do perform them. The reason is that other powerful incentives for performance exist, perhaps the most important of which stem from information-gathering by other firms and consumers. ${ }^{71}$ Unreliable firms lose good

6. See text accompanying notes 32-48 supra.

70 See generally R. PosNer, supra note 6, at 430-59.

${ }^{71}$ See Dohan, supra note 10, at 434; Leff, supra note 11, at 25-36. 
will; unreliable consumers lose good credit ratings. These sanctions arguably make legal incentives to perform unnecessary. ${ }^{72}$

The flaw in such an argument is that these informal incentives are costly $;^{73}$ to the extent that inadequate legal incentives cause excessive use of informal incentives, economic efficiency suffers. The costs involved here take several forms. Sometimes a cash outlay is necessary, for example, when information is purchased from a credit agency. More frequently, the cost is the time of a consumer or producer. ${ }^{74}$

Several indirect costs may exist as well. First, reputation is not necessarily a reliable indicator of actual performance, so reputational incentives may be somewhat erratic in their operation. Second, business reputation may be a difficult asset to protect. A single dramatic controversy witl a consumer can have a disproportionate impact on reputation. Consequently, some businesses may become overcautious and conservative in their actions. ${ }^{75}$ Third, leavy rehance on precontractual information disrupts the free operation of the market. Customers will tend to deal witl sellers with whom they have dealt before and will tend not to engage in a widespread searcl for sellers. As a result, their willingness to shop for better prices can decrease. ${ }^{78}$ Furthermore, entry by new sellers becomes more difficult, because a reputation for reliability cannot be immediately established." Altliough these effects on the behavior of firms are difficult to quantify, they nevertheless represent real

72 See Barton, supra note 28, at 299-300. See also Macaulay, Elegant Models, Empirical Pictures, and the Complexities of Contract, 11 LAw \& Soc. Rev. 507 (1977); Schwartz, supra note 13, at 282.

7s See Leff, supra note 11, at 28.

74 The considerable time required for gathering information should not be underestimated. The cost of such time can be quite high, because leisure time is a very valuable consumer good. See J. HrrshleIfER, supra note 17, at 156-57; Williamson, Assessing Vertical Market Restraints: Antitrust Ramifications of the Transaction Cost Approach, $127 \mathrm{U}$. PA. L. Rev. 953, 977 (1979).

${ }^{75}$ See Leff, supra note 11 , at 26 . Reputation may sometimes provide too effective a sanction, thus discouraging desirable breaches or even actions that do not breach the contract.

78 The risk of dealing with new sellers essentially amounts to an increased cost of search. On the relationship between prices and search costs, see Ioannides, Market Allocation through Search: Equilibrium Adjustment and Price Dispersion, 11 J. ECON. THEORY 247 (1975).

77 A classic example of this effect is the young lawyer entering practice, who often must endure a lengthy time before establishing a clientele. One of the primary purposes of contract law is to encourage trade with "outsiders." See Landa, supra note 46, at 916. 
costs, because they impede the market's movement toward equilibrium. ${ }^{78}$

To see the economic effects of information-acquisition costs, assume that in an otherwise purely competitive market with demand curve $Q=D(P)$ and supply curve $Q=S(P)$, buyers must incur a cost of $\mathrm{C}$ in each transaction to locate reliable sellers. This information cost las the same effect as a tax on transactions, ${ }^{79}$ as sllown in Figure 3. The equilibrium in the absence of this cost is $\left(P_{0}, Q_{0}\right)$. When the seller's price is $P$, buyers experience an effective cost of $P+C$. Hence, the demand curve slifts to the left. The new demand curve is $D^{\prime}(P)$, and the new equilibrium is at $\left(P_{1}, Q_{1}\right)$. The sliaded region $A$ represents the loss to sellers on goods no longer sold, and region $B$ represents their loss (and the buyers' gain) because of the price decline. The triangular region $C$ is the consumer's "deadweight" loss. At the original equilibrium price $P_{o}$, all but the marginal buyer would lave been willing to pay more than $P_{0}$. The quantity decrease from $Q_{0}$ to $Q_{1}$ forces some of these buyers out of the market. Area $C$ represents the price above $P_{o}$ that these buyers would have been willing to pay; in a sense, it represents tlieir lost "profits." surplus, is not matcled by any increase in seller's profits, area $C$ represents the efficiency loss resulting from information costs.

2s One result of this is greater price dispersion and the existence of supercompetitive prices. See Schwartz, supra note 13 , at 281,300 .

70 See J. HiRSHLEIFER, supra note 17, at 32-33, 203-04.

so See id. at 184-95. 
FIGURE 3

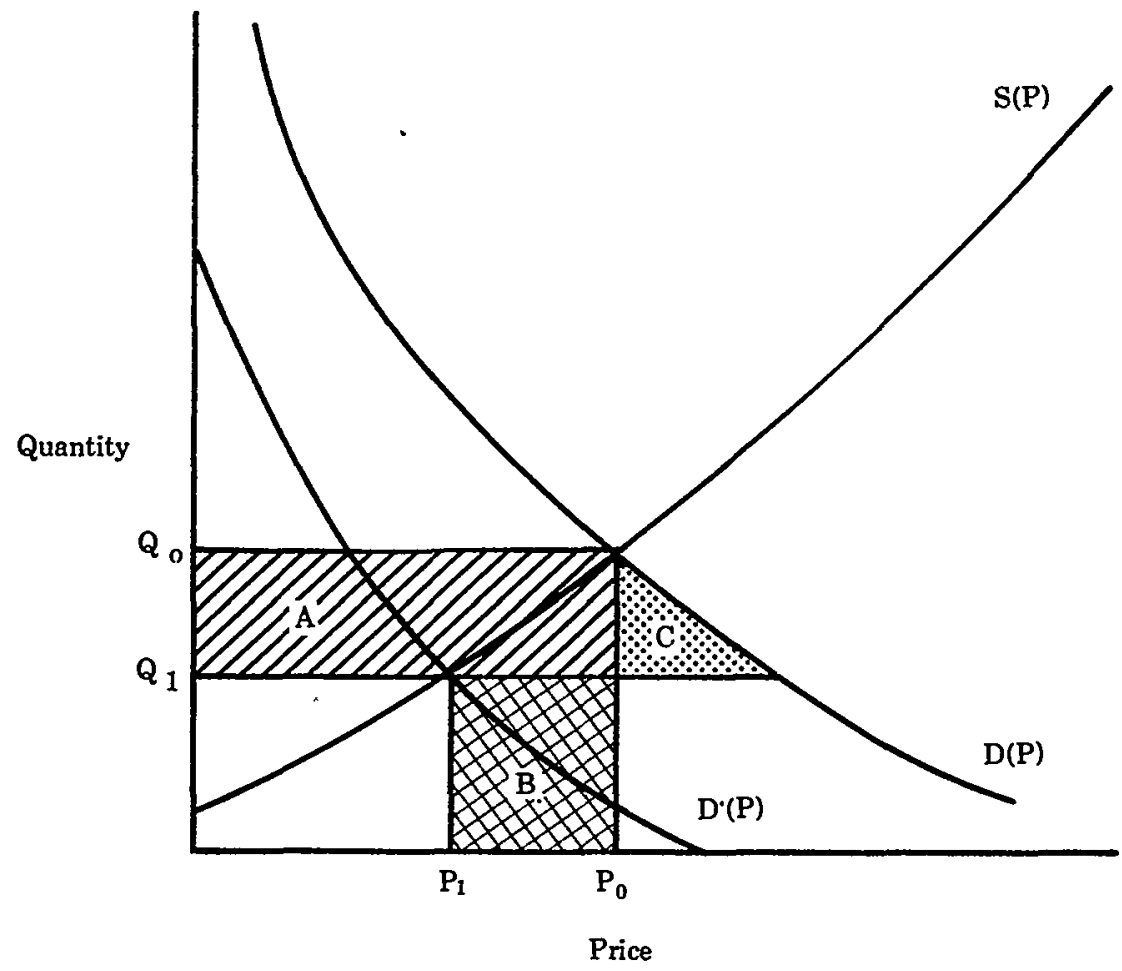

An additional complication is that when some buyers are careful, they create an incentive for sellers to be reliable. An increase in the number of reliable sellers also benefits careless buyers, by increasing their chances of randomly stumbling on a reliable seller. Thus, care by one buyer benefits otler buyers and reduces the efficiency loss from information costs. These other buyers may become freeriders, investing nothing in care themselves. The result is an underinvestment in total care by buyers. ${ }^{81}$ As Appendix $\mathrm{C}$ demonstrates, this effect can be so extreme that no buyer invests in

"The effect resembles the problem of "free riders" in pollution control. Although everyone collectively may benefit from use of pollution-control devices on cars, each individual would prefer not to install the devices. The result may be that no one will install these devices. 
precontractual information, even though such investment would benefit the buyers. ${ }^{82}$

Precontractual information-gathering by buyers thus suffers from two serious drawbacks as a substitute for an adequate legal enforcement system. First, because it is costly, it acts as a tax on transactions and decreases output. Second, an optimum level of imvestment in information-gathering is difficult to obtain because this activity creates positive externalities and encourages free-riders. These flaws, however, do not necessitate the conclusion that allowing adequate damages is always preferable to this method of social control. Rather, the costs of informal enforcement must be considered and weighed against the costs of legal enforcement. When the need for supercompensatory damages is uncertain, use of informal sanctions may be preferable. When these informal sanctions seem particularly inefficient, the argument for supercompensatory damages is strengthened. Because this assessment is difficult to make in the abstract, the next section considers the desirability of supercompensatory damages for breach of construction contracts.

\section{Economic Efficiency and Damages for Breach of Construction Contracts}

This section examines the present common-law approach to damages in the context of construction contracts and then applies the economic analysis of the preceding sections to this issue. Despite its general adherence to the strict-compensation principle, the common law provides indirectly for supercompensatory damages in some situations. The economic analysis, however, suggests the need for greater availability of supercompensatory damages.

\section{A. The Common-Law Approach}

The case law deals with two separate situations. In one situation, the owner refuses to make the final installment payment after discovering the contractor's breach. Collection of the unpaid installment depends on whether the contractor has "substantially per-

\footnotetext{
82 See generally P. Diamond \& M. Rothschild, Uncertainty in Economics 235-307, 459. 574 (1978).
} 
formed." When the contractor's suit is not permitted, he is in effect penalized and the owner is allowed to retain supercompensatory damages. In the second situation, the owner files an affirmative claim for damages, either for return of payment made before discovering the breach or as a counterclaim to the contractor's claim for the unpaid balance. In the owner's suit, the issue is whether the measure of damages should be the diminution in the building's market value caused by the breach or the cost of correcting the defect. ${ }^{84}$ When the cost of correction exceeds the diminution in market value, awarding damages based on the correction cost may amount to a form of supercompensatory damages.

Breach of a construction contract therefore gives rise to two issues. First, did the contractor substantially perform, thereby allowing him to sue for the unpaid contract price? Second, what is the measure of damages for breach by the contractor? Courts and commentators often fail to separate clearly their analysis of these two issues, perhaps because cases in which courts refuse to award cost of completion often involve substantial performance. The proper measure of damages does not necessarily depend, however, on substantial performance. ${ }^{85}$

Although the issue of substantial performance is generally one of

es At one point in the evolution of the common law, strict performance of the contract was apparently a condition of recovery. See Munro v. Butt, 120 Eng. Rep. 275 (K.B. 1858); Ellis v. Hamlen, 128 Eng. Rep. 21 (Ex. 1810). See also Harvey v. White, 213 Cal. App. 2d 275, 280, 28 Cal. Rptr. 601, 604 (1963); McKinney, Substantial Performance in Building and Construction Contracts, 28 BeNch \& B. 59, 60-61 (1912). By the heginning of this century, however, the substantial performance rule was firmly established. See Bowen v. Kimbell, 203 Mass. 364, 369-70, 89 N.E. 542, 543 (1909). The doctrine was so well accepted by 1921 that only two student notes discussed Justice Cardozo's now-famous opinion in Jacob \& Youngs, Inc. v. Kent, 230 N.Y. 239, 129 N.E. 889 (1921). See Note, Substantial Performance of an Express Condition Precedent, 21 CoLUm. L. Rav. 582 (1921); Comment, Contracts-Substantial Performance of Condition Precedent, 19 МrсH. L. Rev. 875 (1921). Today, all states follow the substantial performance doctrine. See cases collected in 13 AM. JuR. 2D Building and Construction Contracts § 41 (1964).

This discussion does not consider the effect of a contractor's quantum meruit action, because the availability of such a remedy varies considerably among the jurisdictions. To the extent that a quantum meruit recovery is allowed, the supercompensatory effect is, of course, reduced.

* See, e.g., 5 A. Corbin, supra note 3, §§ 1089-1091; Restatemrnt (Second) of CoNTRACTs, supra note 8, $\S 361-362$. For a discussion of the British and Commonwealtl cases, see Harris, Contract Remedies and the Consumer Surplus, 95 LAw Q. REv. 581 (1979).

s See Karlinski v. P.R. \& H. Lumber \& Constr. Co., 68 N.D. 522, 527, 281 N.W. 898, 901 (1938). 
fact, $^{86}$ the cases do contain some broad guidelines. A finding of substantial performance usually requires that any deviation must be relatively minor and must not substantially affect the purposes of the construction. ${ }^{87}$ The relative value of the actual performance versus the required performance is certainly relevant, but is rarely conclusive and is often difficult to ascertain. ${ }^{88}$

Another inportant element of substantial performance is a good-faith effort to comply with the contract: the defect must not have been "intentional" or "willful." "89 The extent of this "good faith" requirement is not entirely clear. Many cases express the rule in dicta or under circumstances where the performance, even in the absence of "willfulness," might well be regarded as less than substantial. ${ }^{90}$ In a number of cases, however, a willfulness rule was

so The courts have repeatedly stated that no general rule governs the determination of substantial performance. See 3A A. CorBIN, supra note 3, § 706. This rule is well establizlied in New York, see Crouch v. Gutmann, 134 N.Y. 45, 51, 31 N.E. 271, 273 (1892); Glacius v. Black, 50 N.Y. 145, 149 (1872); and in California, see Connell v. Higgins, 170 Cal. 541, 556, 150 P. 769, 775 (1915); Schindler v. Green, 149 Cal. 752, 754, 87 P. 626, 627 (1906); 1st Olympic Corp. v. Hawryluk, 185 Cal. App. 2d 832, 836, 8 Cal. Rptr. 728, 730 (1960).

${ }_{87}$ See Lowy v. United Pac. Ins. Co., 67 Cal. 2d 87, 93, 429 P.2d 577, 581, 60 Cal. Rptr. 225, 229 (1967); Connell v. Higgins, 170 Cal. 541, 150P. 769 (1915); Elliott v. Caldwell, 43 Minn. 357, 360, 45 N.W. 845, 846 (1890); Spence v. Ham, 163 N.Y. 220, 225, 57 N.E. 412,413 (1900); Crouch v. Gutmann, 134 N.Y. 45, 51, 31 N.E. 271, 273 (1892); 3A A. CorBin, supra note $3, \S 706$.

se SA A. Corbin, supra note $3, \S 705$.

so See, e.g., Crouch v. Gutmann, 134 N.Y. 45, 51, 55-56, 31 N.E. 271, 273, 274-75 (1892); Lewis v. Barsuk, 55 A.D.2d 817, 818, 389 N.Y.S.2d 952, 953 (1976) (plaintiff must establish deviations were neither willful nor substantial; no substantial performance found where defect could affect structural integrity); Cassino v. Yacevitch, 261 A.D. 685, 27 N.Y.S.2d 95 (1941) (rule of substantial performance applies where "builder lias in good faith intended to comply"; lower court found 22 defects, some structural, and no substantial performance). But see Van Clief v. Van Vechten, 130 N.Y. 571, 579-80, 29 N.E. 1017, 1019 (1892) ("willful refusal by the contractor to perform the contract" prohibits recovery); Cramer v. Esswein, 220 A.D. 10, 220 N.Y.S. 634 (1927) (plaintiff-contractor installed seven radiators instead of eight, used secondhand tub and washbasin, and willfully removed furnace parts; court held no substantial performance). In neither Van Clief nor Cramer did the court indicate how substantial the defects were in relation to the entire contract, but botll courts specifically relied on the willfulness doctrine.

0 See, e.g., Cassinelli v. Stacy, 238 Ky. 827, 38 S.W.2d 980 (1931) (no substantial performance where structural defects in walls, roof, and foundation amounting to approximately $\$ 2,000$ on a $\$ 7,000$ contract); Anderson v. Primgle, 79 Minn. 433, 82 N.W. 682 (1900) (no substantial performance where plaintiff performed only $60 \%$ of contract); Elliott v. Caldwell, 43 Minn. 357, 45 N.W. 845 (1890) (no suhstantial performance; "willful" breaches also pervasive and incapable of repair without rebuilding); Filbert v. Philadelplia, $181 \mathrm{~Pa}$. 530, 37 A. 545 (1897) (finding contractor substantially performed); Tex-Craft Builders, Inc. v. Allied Constructors, Inc., 465 S.W.2d 786 (Tex. Civ. App. 1971) (no substantial perform- 
clearly applied. For example, in Gillespie Tool Co. v. Wilson, ${ }^{91}$ the plaintiff liad used a smaller casing than the contract specified for boring a gas well..$^{92}$ Despite the plaintiff's claim that the smaller casing was "just as good," the court refused to find substantial performance because the plaintiff had willfully departed from the contract. $^{93}$ On the otlier hand, cases finding substantial performance despite a "willful breach" generally liave involved intentional but good-faith deviations from the contract specifications. ${ }^{94}$ Looking at the willfulness cases as a group, the most important factor seems to be whetler the deviation from specifications was intentional but well-meaning or whether it involved deliberate bad faith.

The issue of the owner's damages often arises in conjunction witl that of substantial performance when the contractor sues for the balance due and the owner counterclaims for damages. ${ }^{95}$ Every

ance where contract only 75-85\% complete); Kreyer v. Driscoll, 39 Wis. $2 \mathrm{~d}$ 540, 159 N.W.2d 680 (1968) (no substantial performance where one-half of heating, plumbing, electrical, and tiling work unfinished); Foeller v. Heintz, 137 Wis. 169, 118 N.W. 543 (1908) (holding contractor had substantially performed).

$1123 \mathrm{~Pa} .19,26,16$ A. 36, 37-38 (1888). See also McAdams v. Smith, $65 \mathrm{~Pa}$. Super. Ct. 568,571 (1917).

$\because 123 \mathrm{~Pa}$. at $26,16 \mathrm{~A}$. at $37-38$.

's Similarly, in Shell v. Schmidt, 164 Cal. App. 2d 350, 330 P.2d 817 (1958), cert. denied, 359 U.S. 959 (1959), a contractor was not allowed to introduce evidence that willful deviations from the contract specifications did not affect the structure's usefulness.

* See, e.g., Morello v. Levakis, 293 Mass. 450, 200 N.E. 271 (1936). In Morello the court found substantial performance despite a deliberate deviation from tbe brick mortar mix specified in the contract. The court stressed that the mortar was changed because the parties mutually agreed to change the brick used, that it performed satisfactorily, and that the contractor beheved it best served the purpose. Similarly, in Holt v. Sims, 94 Minn. 157, 102 N.W. 386 (1905), the court refused to apply a willfulness rule where the contractor substituted a better boiler than that specified in the contract because he was unable to secure the specified boiler. See also Cassmelli v. Stacy, 238 Ky. 827, 838, 38 S.W.2d 980, 985 (1931). In otber cases, the courts have refused to apply the willfulness doctrine where the contractor's breach was in response to a supposed breach by the owner. See, e.g., Zarthar v. Saliba, 282 Mass. 558, 185 N.E. 267 (1933); Mathis v. Thımderbird Village, Inc., 236 Or. 425, 441-42, 389 P.2d 343, 351 (1964).

os See, e.g., Connell v. Higgins, 170 Cal. 541, 150 P. 769 (1915); Campbell v. Koin, 154 Colo. 425, 391 P.2d 365 (1964); P \& M Constr. Co. v. Hammond Ventures, Inc., 3 Mich. App. 306, 142 N.W.2d 468 (1966); Odgers v. Held, 58 Wash. 2d 247, 362 P.2d 261 (1961); J.G. Jansen, Inc. v. Rilling, 203 Wis. 193, 232 N.W. 887 (1930); Foeller v. Heintz, 137 Wis. 169, 118 N.W. 543 (1908). Many cases, however, involve a simple suit by the owner for damages, so that the substantial performance issue is absent. See, e.g., Levesque v. D \& M Builders, Inc., 170 Conn. 177, 365 A.2d 1216 (1976); Johnson v. Flammia, 169 Conn. 491, 363 A.2d 1048 (1975); Mitchell v. Carlson, 132 Mont. 1, 313 P.2d 717 (1957); Groeteke v. Stubbs, 196 
jurisdiction considering the issue has applied some form of a costvalue rule. In most states, the owner receives the cost of completion unless this cost greatly exceeds the diminution in value. ${ }^{.8}$ This willingness to award damages in excess of diminution in market value probably reflects a recognition that the structure's actual value to the owner may exceed its market value. ${ }^{97}$ Particularly where personal dwellings have been involved, courts have awarded the cost of repair because of the difficulty of measuring the intangible loss to the plaintiff. ${ }^{98}$ A Florida court justified such an exception on the following grounds:

If a proud householder, who plans to live out his life in the house of his dreams orders a roof of red barrel tile and the roofer instead installs a purple one, money damages for the reduced value of the house may not be enough to offset the strident offense to aesthetic sensibilities . . . .90

Neb. 114, 241 N.W.2d 538 (1976); Beik v. American Plaza Co., 280 Or. 547, 572 P.2d 305 (1976); Prier v. Refrigeration Eng'r Co., 74 Wash. 2d 25, 442 P.2d 621 (1968).

so See Blecick v. School Dist. No. 18, 2 Ariz. App. 115, 406 P.2d 750 (1965) (upholding $\$ 12,000$ cost-of-repair award); Carter v. Quick, 263 Ark. 202, 563 S.W.2d 461 (1978) (upholding $\$ 4,000$ cost-of-repair award although house as built was worth more than contract price); Izumi v. Kwan Doo Park, 44 Hawaii 123, 351 P.2d 1083 (1960) (upholding $\$ 13,000$ cost-ofrepair award for structural defects in house); Hafer v. Horn, 95 Idaho 621, 515 P.2d 1013 (1973) (upholding $\$ 5,950$ cost-of-repair award on $\$ 23,590$ contract); J-M Builders \& Supplies Corp. v. McIntyre, 56 Ill. App. 3d 714, 372 N.E.2d 420 (1978) (upholding $\$ 3,000$ costof-repair award on contract to install siding); Di Bernardo v. Gunneson, 65 A.D.2d 828, 409 N.Y.S.2d 838 (1978) (upholding $\$ 30,000$ cost-of-repair award for replacement of defective roof and completion of home); Daniels v. Albert J. Corey Co., 2 Ohio App. 2d 297, 208 N.E.2d 150 (1965) (upholding $\$ 3,500$ cost-of-repair award on $\$ 23,000$ contract); W.G. Slug Seed \& Fertilizer, Inc. v. Paulsen Lumber Co., 62 Wis. 2d 220, 214 N.W.2d 413 (1974) (overturning $\$ 15,500$ cost-of-repair award that increased building value by $\$ 5,000$ ); Mann $v$. Clowser, 190 Va. 887, 59 S.E.2d 78 (1950) (upholding $\$ 7,500$ cost-of-repair award on $\$ 10,000$ contract). This rule leads to a rather peculiar result. If loss of value is $\$ 10,000$ and "unreasonably high" means "in excess of $150 \%$," an owner whose cost to complete is $\$ 14,000$ receives a $\$ 14,000$ recovery, but an owner whose cost to complete is $\$ 16,000$ receives only $\$ 10,000$. See Farnsworth, supra note 3 , at 1175 .

o7 See, e.g., Restatement (Second) of Contracts, supra note 8 , $\$ 362$, Comment c.

${ }^{98}$ For example, Alabama generally adheres to dininished market value as the measure of damages, see, e.g., Braswell v. Malone, 252 Ala. 323, 327-28, 78 So. 2d 631, 635 (1955), but has recognized an exception for noncommercial structures involving personal taste, see, e.g., Fox v. Webb, 268 Ala. 111, 118-19, 105 So. 2d 75, 82 (1958). Other jurisdictions have adopted a similar rule. See Edgar v. Hosea, 210 So. 2d 233, 234 (Fla. Dist. Ct. App. 1968); Edenfield v. Woodlawn Manor, Inc., 62 Tenn. App. 280, 285-91, 462 S.W.2d 237, 240-42 (1971). See also Thoinas v. Warrenburg, 92 Kan. 576, 577, 141 P. 255, 256 (1914); McCullogh v. S.J. Hayde Contracting Co., 82 Kan. 734, 737, 109 P. 176, 177 (1910).

9 Gory Assoc. Indus., Inc. v. Jupiter Roofing \& Sheet Metal, Inc., 358 So. 2d 93, 95 (Fla. 
While some homeowners probably use the damages to repair their houses, the actual loss (in subjective terms) is likely somewhere between cost of repair and loss in market value. In such cases, the owner receives supercompensatory damages. As in the substantial performance area, some reason also exists to believe that courts have penalized bad-faith breaches. When repair or completion costs exceed market-value loss, many courts award the higher measure of damages if the breach was willful. ${ }^{100}$

Thus, although strict compensation is the dominant judicial purpose in awarding contract damages, the cases indicate that supercompensatory damages are sometimes awarded. Furthermore, penalties for bad faith may be imposed more frequently at the trial court level, ${ }^{101}$ where the vagueness of common-law damage rules and the presentation of conflicting evidence frequently give juries and judges wide discretion in fixing damages. Their disapproval of intentional or bad-faith breaches may well influence the exercise of this judgment. Hence, in its actual day-to-day operation, the legal system may regularly attach a penalty to certain breaches.

\section{B. Economic Analysis}

In terms of the economic models presented earlier, the primary enforcement problem here relates to information costs. It is expensive for the owner to select subcontractors and supervise construction. If general contractors were not more efficient than owners in performing these functions, owners would have little reason to use them. ${ }^{102}$ Because inspection is costly for the owner, the general contractor has an incentive to cheat. ${ }^{103} \mathrm{He}$ can do so by dehberately violating the specifications or by reducing supervision of the subcontractors' work below the optimum level. Because the owner

Dist. Ct. App. 1978).

${ }^{100}$ See, e.g., Shell v. Schmidt, 164 Cal. App. 2d 350, 358, 330 P.2d 817, 822 (1958); Henderson v. Oakes-Waterman Builders, 44 Cal. App. 2d 615, 618-19, 112 P.2d 662, 664-65 (1941); McKee v. Wheelus, 85 Ga. App. 525, 528, 69 S.E.2d 788, 791 (1952); Groves v. John Wunder Co., 205 Minn. 163, 165-67, 286 N.W. 235, 236-38 (1939); Morgan v. Gamble, 230 Pa. 165, 173, 79 A. 410, 413 (1911). But see Peevyhouse v. Garland Coal \& Mining Co., 382 P.2d 109 (Okla. 1962).

101 See 5 A. Corbin, supra note $3, \S 1077$, at 440.

${ }^{102}$ See J. SwEET, supra note 12 , at $235,243-44$. The role of monitoring and information costs in construction contracts is addressed by Schwartz, supra note 13, at 277, 296.

${ }^{103}$ See Alchian \& Demsetz, supra note 53, at 780 (costly detection creates incentives to breach). 
cannot perfectly monitor the general contractor's behavior, compensatory damages will not lead to economically optimum conduct. ${ }^{104}$ This conclusion is reinforced by the substantial enforcement costs the owner can expect to encounter. ${ }^{105}$

Supercompensatory damages can, however, have undesirable side effects. Unduly high damages may force the contractor to overinvest in monitoring subcontractors. At some point, the cost of increased supervision exceeds the marginal benefits to the owner, who would not wish to force the general contractor past this point of diminishing returns. Thus, although a contract appears to call for perfect compliance with the specifications, the parties probably do not intend to obtain this result. ${ }^{108}$ They instead probably hope to achieve a high but imperfect level of compliance, with side-payments or price reductions to compensate for any shortfall. ${ }^{107}$ The Uniform Commercial Code speaks of a somewhat similar situation as involving "a non-conforming tender which the seller had reasonable ground to believe would be acceptable with or without money allowance." ${ }^{108}$ Clearly, supercompensatory damages should not be awarded in this situation.

Supercompensatory damages may be justified, however, where the breach results from the contractor's failure to maintain adequate supervision. In determining the adequacy of supervision, a detailed economic inquiry may be extremely difficult and prohibitively expensive. A court might instead look to the custom of the trade-the "usages currently observed by the great majority of decent dealers, even though dissidents ready to cut corners do not agree." 100 Presumably, the customary conduct of the majority of "decent dealers" is cost-justified; otherwise they would contract for less burdensome conduct. Unilateral deviations from this custom

\footnotetext{
106 See text accompanying notes $49-69$ supra.

105 See text accompanying notes 26-48 supra.

108 Courts have recognized the impracticality of full performance as one basis for the substantial performance doctrine. See Cassinelli v. Stacy, 238 Ky. 827, 838, 38 S.W.2d 980, 985 (1931); Glacius v. Black, 50 N.Y. 145, 148 (1872); Dixon v. Nelson, 79 S.D. 44, 48, 107 N.W.2d 505, 507 (1961).

${ }_{107}$ See Fargo Mach. Tool Co. v. Kearney \& Trecker Corp., 428 F. Supp. 364, 373 (E.D. Mich. 1977) (stating that the parties to the contract for sale of complex machinery contemplated the necessity of minor repairs after delivery). See generally Schiro, supra note 2, at

10 U.C.C. § 2-508(2).

${ }^{109}$ Id. § 1-205, Comment 5.
} 1776. 
are unlikely to be justifed when the full cost to the other party is considered, and such breaches are therefore unlikely to promote efficiency. As shown earlier, however, compensatory damages may often fail to deter these breaches sufficiently.

The accepted practice of the trade is also hikely to be the standard contemplated by the parties. ${ }^{110}$ When a contractor knows his conduct would be unacceptable if promptly detected, he has violated the assumption of commercial good faith that underlies the contract. These breaches should be deterred. Whether compensatory damages will provide an adequate deterrent depends on the cost of detection, litigation expenses, and other possible flaws in the compensation mechanism, such as the difficulty of measuring damages when much of the product's value to the buyer is subjective and idiosyncratic. ${ }^{111}$

Because of substantial detection and enforcement costs some form of supercompensatory damages may be appropriate whenever the contractor fails to maintain a commercially reasonable level of supervision of a subcontractor. Thus, supercompensatory damages are arguably appropriate whenever the general contractor's negligence causes a delay or deviation from specifications. The case for supercompensatory damages is strongest when the delay or deviation from specifications is not negligent but willful. Such a breach indicates that informal control mechanisms, sucl as consumer reliance on trade reputation, ${ }^{112}$ are not functioning adequately.

As discussed previously, the common law indirectly allows for supercompensatory damages in circumstances suggestive of bad faith, such as a lack of substantial performance ${ }^{113}$ or a willful breach. ${ }^{114}$ Finally, the argument for supercompensatory damages is probably strongest when a personal dwelling is involved. The owner is hikely to have high search and supervision costs, litigation expenses disproportionate to damages, and special problems in establishing damages for subjective values. ${ }^{115}$ The analysis presented

110 The contracting parties probably expect some technical breaches, such as minor delays or trivial deviations from specifications. See cases cited at notes 106-07 supra.

11 See Goetz \& Scott, supra note 28, at 572-74; Kronman, supra note 29, at 360-64.

132 See text accompanying notes 70-82 supra.

113 See text accompanying notes 86-94 supra.

114 See text accompanying notes 89-94 \& 100 supra.

115 For a discussion of the trade-off created by higher damages, see text accompanying notes 98-99 supra. 
in this article is consistent with the common-law treatment of these cases.

\section{Suggested Approach}

The clearest result of this article's investigation of the economic effects of compensatory damages is that no particular reason exists to believe that compensatory damages are economically optimum. ${ }^{116}$ The current bias in damage rules toward undercompensation seems questionable, because any economic harm from overcompensation is at best purely speculative. A general relaxation of restrictions on contract damages seems to be needed.

Beyond liberalizing rules for compensatory damages, deliberate overcompensation of plamtiffs may sometimes also be justified, particularly in two situations. First, difficulty of detection, costs of litigation, or difficulty in measuring compensatory damages may be so great as to make compensatory damages almost worthless as a means of inducing performance. Second, the breaching party may have failed to meet the standards of commercial reasonableness prevalent among honest business people. These situations are likely to overlap, as bad-faith breach is clearly more likely when nonlegal enforcement mechanisms have broken down.

These conclusions suggest that courts should establish new damage rules to cover these situations. One solution that deserves exploration is application of tort damage rules. In effect, these situations could be classified as "tortious breach of contract." Such a development may already have occurred with insurance contracts, where an insurer las an implied duty of good faitl in the performance of the contract. ${ }^{117}$ Courts have implied a "best efforts" obligation not unhike those implied in other contractual settings. ${ }^{118}$ Under statutes in force in many states, breach of this implied obh-

\footnotetext{
116 This would be an important result even if the economic benefits of increasing damages were completely unknown. See notes 70-82 supra and accompanying text. When noneconomic arguments are persuasive, economic considerations should not present a problem.

117 See 7C J. Appleman, Insurance Law \& Practice § 4712 (rev. ed. 1979); 44 Am. JuR. 2D Insurance § 1530 (1969); Annot., 40 A.L.R.2d 168 (1955).

116 Compare American Mut. Liab. Ins. Co. v. Cooper, 61 F.2d 446 (5th Cir. 1932), cert. denied, 289 U.S. 736 (1933) (insurance company that made no investigation of the merits of a case and refused settlement guilty of bad faith), with Wasserman v. Buckeye Union Cas. Co., 32 Ohio St. 2d 69, 290 N.E.2d 837 (1972) (where sufficient evidence existed to raise questions as to cause of injuries, insurer's decision to appeal not made in bad faith).
} 
gation can lead to awards of punitive damages and attorneys' fees if, for example, the insurer wrongfully refuses a settlement. ${ }^{119} \mathrm{De}-$ spite the contractual basis of these suits, courts tend to look to tort law in deciding the issues. ${ }^{120}$ This development seems economically justified. Under the theory presented in this article, supercompensatory damages would be appropriate whenever the insurer departs from reasonable commercial standards-that is, whenever the breach is characterized by negligence or bad faith. Perhaps in response to economic factors, ${ }^{121}$ these statutes allow courts to award supercompensatory damages for breach under the rubric of tort law. This analogy to tort law offers a promising method of developing damage rules for other situations in which supercompensatory damages are appropriate. ${ }^{122}$

Another way of dealing with the need for supercompensatory damages is to allow the parties to contract for them. Presumably, they will be included in the contract only when such damages are economically justified. Thus, this analysis supports the arguments that others have made for an end to the traditional rules agamst penalty clauses. ${ }^{128}$ Contractual forfeitures should be favored for the same reason. If courts are unwilling to abrogate completely the traditional rules agamst penalty and forfeiture clauses, they should at least do so when such clauses are directed against commercial bad faith or are used to compensate for difficulties in detecting and remedying breaches.

\footnotetext{
110 See, e.g., In.. Rev. Stat. ch. 73, § 767 (1979 Supp.); Tex. Ins. Code Ann. art. 3.62 (Vernon 1963); 16 R. Anderson, Couch on Insurance \$ 58:1 (2d ed. 1966); 6A J. Appleman, supra note 117, § 4031, at 28 .

120 See, e.g., Richardson v. Employers Liab. Assurance Corp., 25 Cal. App. 3d 232, 244-46, 102 Cal. Rptr. 547, 555-58 (1972).

"si Some courts, for example, have construed their state's statutes as compensation for the cost of collecting a debt. See Bankers Reserve Life Co. v. Crowley, 171 Ark. 135, 147, 284 S.W. 4, 9 (1926). Other courts have specifically noted that the statutes exist to ensure no diminution in the recovery received or to ensure plaintiffs' economic incentive to sue recalcitrant insurance companies even when small amounts of money are involved. See Willis v. American Nat'l Life Ins. Co., 287 S.W.2d 98, 105 (Mo. App. 1956); Hubbard v. Lumbermen's Mut. Cas. Co., 24 N.C. App. 493, 497, 211 S.E.2d 544, 546 (1975). See generally 16 R. ANDERSON, supra note 119, §§ 58:3-:4; 6A J. APpleman, supra note 117, § 4031.
}

122 Another promising possibility is use of restitutionary recovery. See note 46 supra.

2ss See Goetz \& Scott, supra note 28. 


\section{Conclusion}

This article has investigated the economic effects of compensatory damages and concluded that compensatory damages are not necessarily optimum. All measures of damages are economically equivalent in the absence of transaction costs. An economic analysis of contract damages must therefore focus on the effects of transaction costs and imperfect information. When these effects are taken into account, the case for exclusive reliance on compensatory damages is weakened. Given the difficulty of detecting and litigating breaches, compensatory damages may be an insufficient deterrent to economically undesirable breaches, and supercompensatory damages may be justified. ${ }^{124}$

134 This article has had much to say about economic efficiency and relatively little to say about justice. It would be disingenuous to pretend that my views on this topic are derived solely from mathematical modeling or economic theory. Current law is far too tolerant of bad faith and shady practice. The puhlic should not have to rely on careful shopping for protection against unethical dealers. Nor are inadequate legal controls acceptable simply because most businessmen have higher ethical standards than the law requires. Law should support, not ignore, widely held moral standards. The common law of contract damages has conspicuously failed to perform this role by declining to stigmatize contractual breaches that most people would view as unethical. This article calls for an improvement in the morality of the law. As it happens, in this context, morality apparently coincides with economic efficiency. 


\section{Appendix A}

The following proof demonstrates that the effect of enforcement costs is to depress both supply and demand under the assumptions of Model IB. ${ }^{125}$ Assume that $\left(Q_{0}, P_{0}\right)$ is the initial equilibrium (before introducing enforcement costs), and $A(P)$ is the probability distribution of outside bids. Let $B(P)$ be the probability distribution of the value of the goods to the original buyer. If transaction costs are zero, the seller's expected gain from outside sales is

$$
\text { (A1) } \int_{K}^{\infty} \int_{P}^{\infty} \frac{(X-P) \cdot A(X) \cdot B(P)}{Q} d X d P
$$

where $\mathrm{K}$ is the contract price.

The introduction of transaction costs reduces each seller's profits by

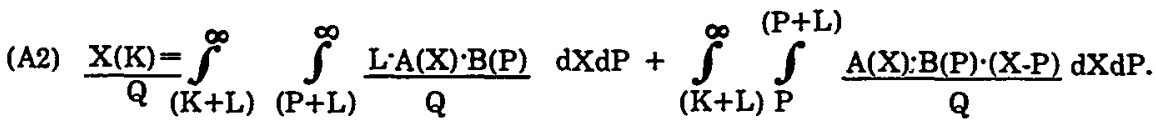

$\mathrm{X}(\mathrm{K}) / \mathrm{Q}$ is the sum of the litigation expenses in cases where the outside bid is profitable enough to favor breach (but where the original buyer's damages exceed his litigation costs) plus the lost profits from cases in which breach is no longer profitable because of litigation costs. $X(P)$ will be positive if $A(X)$ and $B(P)$ are positive anywhere in the relevant region.

When transaction costs were zero, the marginal cost for any seller entering at price $P$ was $P$. Thus, if $Q=S(P)$, the $Q^{\text {th }}$ seller had marginal cost $P$. The $Q^{\text {th }}$ seller will no longer be willing to enter at price $P$, however, since the expected profit at $P$ is now reduced by $X(P) / Q$. Formerly, entry did not reduce the possible profit from later deals with outside buyers, but now an opportunity cost of this kind is associated with entry. Hence, the supply at $P$ will no longer be $S(P)$, but instead $S\left(p^{\prime}\right)$, where $p^{\prime}$ is the old entry price of the last seller to enter under the new supply conditions. That is, $p^{\prime}$ must satisfy the equation

$$
\text { (A3) } f\left(p^{\prime}\right)=p^{\prime}+\frac{X(P)}{Q}=P .
$$

125 See text accompanying notes 32-36 supra. 
Equation (A3) will have a solution if $P>f(0)$. We will then have $f(P)>P>f(0)$. Since $f(P)$ is continuous, there exists a $p^{\prime}$ such that $f\left(p^{\prime}\right)=P$. On the other hand, if $P<f(0)$, even sellers who would enter previously at a price just above zero will now be unwilling to enter. So, quantity will now be zero. Because $X(P)$ is positive, we see that $\mathrm{p}^{\prime}<\mathrm{P}$, and therefore $\mathrm{S}\left(\mathrm{p}^{\prime}\right)<(\mathrm{P})$. Litigation costs will thus decrease the effective supply at any given price.

The same analysis apphes to the buyer. The $Q^{\text {th }}$ buyer who was willing to buy only at price $P$ will no longer be willing to buy at the same price. Absent litigation costs, this buyer could always be assured of obtaining the desired value from his bargain, either in the form of the good itself or in the form of compensatory damages. Now, however, these benefits are offset by the expected hitigation costs or by the loss of bargain if htigation is not worthwhile. This decrease in expectations is

$$
\text { (A4) } \frac{\mathrm{Z}(\mathrm{K})}{\mathrm{Q}}=\int_{(\mathrm{K}+\mathrm{L})(\mathrm{P}+\mathrm{L})}^{\infty} \frac{\mathrm{L} \cdot \mathrm{A}(\mathrm{X}) \cdot \mathrm{B}(\mathrm{P})}{\mathrm{Q}} \mathrm{dX} \mathrm{XP}+\int_{\mathrm{K}}^{(\mathrm{K}+\mathrm{L})} \int_{\mathrm{P}}^{\infty} \frac{\mathrm{A}(\mathrm{X}) \cdot \mathrm{B}(\mathrm{P}) \cdot(\mathrm{P}-\mathrm{K})}{\mathrm{Q}} \mathrm{dX} \mathrm{dP}
$$

Thus, entry will be delayed until the price declines enough to compensate for this added expected cost (which could be considered an insurance premium at the time of contracting). As in the case of sellers, we see that at price $P$ only $D\left(p^{\prime}\right)$ buyers will be willing to buy, where $p^{\prime}$ satisfies the equation

$$
\text { (A5) } \mathbf{g}\left(\mathrm{p}^{\circ}\right)=\mathrm{p}^{*}-\frac{\mathrm{Z}(\mathrm{P})}{\mathrm{Q}}=\mathrm{P}
$$

If, for some sufficiently large $\mathrm{P}^{*}$, we have $\mathrm{g}\left(\mathrm{P}^{*}\right)>\mathrm{P}$, then a solution $\mathrm{p}^{\prime}$ exists such that $\mathrm{p}^{\prime}>\mathrm{P}$ and $\mathrm{g}\left(\mathrm{p}^{\prime}\right)=\mathrm{P}$. On the other hand, if no such $\mathrm{P}^{*}$ exists, even buyers who once were willing to buy at extremely high prices are not willing to incur the litigation costs resulting from buying at price $P$; thus demand is evidently now zero. In either case, defining the new demand as $D^{\prime}(P)$, then $D^{\prime}(P)$ $<\mathrm{D}(\mathrm{P})$ for either $\mathrm{D}^{\prime}(\mathrm{P})<\mathrm{D}\left(\mathrm{p}^{\prime}\right)<\mathrm{D}(\mathrm{P})$, (because $\mathrm{p}^{\prime}>\mathrm{P}$ ), or $D^{\prime}(P)=0$.

If the new supply curve is $\mathrm{S}^{\prime}(\mathrm{P})$, it has now been shown that $\mathrm{D}^{\prime}(\mathrm{P})<\mathrm{D}(\mathrm{P})$ and $\mathrm{S}^{\prime}(\mathrm{P})<\mathrm{S}(\mathrm{P})$. 
Appendix $B$

To prove that under the assumptions of Model IIB, an increase in damages creates a Pareto improvement in the equilibrium positions of the parties, ${ }^{128}$ consider first the seller's expected position. For any D, substituting (6) into equation (2)

(B1) $\operatorname{Ex}(\mathrm{S})=\mathrm{X}^{*}\left(\mathrm{P}-\mathrm{C}_{\mathrm{G}}\right)\left(1-\mathrm{X}^{*}\right) \cdot\left(-\left[\frac{\mathrm{C}_{\mathrm{G}}-\mathrm{C}_{\mathrm{D}}}{\mathrm{D}}\right] \cdot \mathrm{D}+\mathrm{P}-\mathrm{C}_{\mathrm{D}}\right)=\mathrm{X}^{*}\left(\mathrm{P}-\mathrm{C}_{\mathrm{G}}\right)+\left(1-\mathrm{X}^{*}\right) \cdot\left(\mathrm{P}-\mathrm{C}_{\mathrm{G}}\right)$ $=\mathrm{P}-\mathrm{C}_{\mathrm{G}}$

Assuming $P$ is fixed, $\operatorname{Ex}(\mathrm{S})$ is constant at equilibrium for all $\mathrm{D}$. To now show that $\operatorname{Ex}(B)$ is an increasing function of $D$ if $P$ is fixed, express equation (1) in the form

(B2) $\operatorname{ExB}(\mathrm{D})=\mathrm{X}^{*}(\mathrm{D})\left(\mathrm{V}_{\mathrm{G}}-\mathrm{P}\right)+\left(\left(1-\mathrm{X}^{*}(\mathrm{D})\right) \cdot\left(\mathrm{V}_{\mathrm{D}}-\mathrm{P}+\mathrm{D} \cdot \mathrm{Y}^{*}(\mathrm{D})\right)\right)-\mathrm{C}\left(\mathrm{Y}^{*}(\mathrm{D})\right)$

$$
\begin{aligned}
& =X^{*}(D)\left(V_{G^{-}}-P\right)+\left(\left(1-X^{*}(D)\right) \cdot\left(V_{D}-P+C_{G^{-}} C_{D}\right)\right) \cdot C\left(Y^{*}(D)\right) \\
& =X^{*}(D)\left(V_{G^{-}} P\right)+\left(\left(1-X^{*}(D)\right) \cdot\left(V_{G^{-}} P\right)\right)+\left(\left(1-X^{*}(D)\right):\left(V_{D^{-}} V_{G}+C_{G^{-}} C_{D}\right)\right) \cdot C\left(Y^{*}(D)\right) \\
& =V_{G^{-}} P+K\left(1-X^{*}(D)\right)-C\left(Y^{*}(D)\right)
\end{aligned}
$$

where $K=V_{D}-V_{G}+C_{G}-C_{D}$. Since $V_{G}>V_{D}+C_{G}-C_{D}, K<0$. Differentiating the final equation with respect to $D$

$$
\text { (B3) } \frac{d \operatorname{Ex}(B)}{d D}=(-K)\left(\frac{d X^{*}(D)}{d D}\right)-\frac{d C\left(Y^{*}(D)\right)}{d D}
$$

It has been shown that $\mathrm{X}^{*}$ is an increasing function of $\mathrm{D}$, and that $\mathrm{Y}^{*}(\mathrm{D})$ is decreasing, so $\mathrm{C}\left(\mathrm{Y}^{*}(\mathrm{D})\right)$ is also decreasing and $\underline{\mathrm{dC}\left(\mathrm{Y}^{*}(\mathrm{D})\right)}<0$. Expression (B3) is thus always greater than 0 . This $\mathrm{dD}$

concludes the proof that $\operatorname{Ex}(B)$ is an increasing function of D. It has already been demonstrated that $\mathrm{Ex}(\mathrm{S})$ is constant. It follows that increasing D increases $\mathrm{Ex}(\mathrm{B})$ without decreasing $\mathrm{Ex}(\mathrm{S})$, so increasing $\mathrm{D}$ always causes a Pareto improvement in equilibrium positions, assuming $P$ is fixed.

126 See text accompanying notes 53-56 \& 62-68 supra. 
This proof of Pareto optimality (but not the discussion in the text) relies on the justifiable assumption that $P$ is constant. Equation (A1) slows that in equilibrium, sellers will sell at $\mathrm{C}_{\mathrm{G}}$. They will not sell at lower prices (since there would then be a negative gain from trade); and they will be unable to sell at higher prices under competition. Hence, $\mathrm{P}=\mathrm{C}_{\mathrm{G}}$, if trade occurs at all at equilibrium. To prove that buyers are willing to pay $C_{G}$, set $P=C_{G}$ in the first line of equation (B2), so that

$$
\text { (B4) } \operatorname{ExB}(D)=X^{*}(D)\left(V_{G}-C_{G}\right)+\left(1-X^{*}(D)\right)\left(V_{D}-C_{G}+D \cdot Y^{*}(D)\right)-C\left(Y^{*}(D)\right) \text {. }
$$

The next step is to ensure Ex B (D) $>0$, or

$$
\text { (B5) } \mathrm{X}^{*}(\mathrm{D})\left(\mathrm{V}_{\mathrm{G}}-\mathrm{C}_{\mathrm{G}}\right)+\left(1-\mathrm{X}^{*}(\mathrm{D})\right)\left(\mathrm{V}_{\mathrm{D}}-\mathrm{C}_{\mathrm{G}}+\mathrm{D} \cdot \mathrm{Y}^{*}(\mathrm{D})\right)>\mathrm{C}\left(\mathrm{Y}^{*}(\mathrm{D})\right) \text {. }
$$

Substituting for $\mathrm{Y}^{*}(\mathrm{D})$ using equation (6) demonstrates tliat inequality (B5) is equivalent to

$$
\text { (B6) } \mathrm{X}^{*}(\mathrm{D})\left(\mathrm{V}_{\mathrm{G}}-\mathrm{C}_{\mathrm{G}}\right)+\left(1-\mathrm{X}^{*}(\mathrm{D})\right)\left(\mathrm{V}_{\mathrm{D}}-\mathrm{C}_{\mathrm{D}}\right)>\mathrm{C}\left(\mathrm{Y}^{*}(\mathrm{D})\right) \text {. }
$$

The derivative of the left side of (B5) is

$$
\text { (B7) } \frac{d X^{*}(D)}{d D} \cdot\left(V_{G}-C_{G}+C_{D}-V_{D}\right) \text {. }
$$

Because $X^{*}$ is an increasing function of $D$, and because $V_{G}$ $V_{D}>C_{G}-C_{D}$ (otlierwise buyers would not desire nondefective goods), the derivative (B7) is always greater than zero, so the left side of inequality (B6) is an increasing function of $\mathrm{D}$. On the other hand, the riglit side of the inequality is a decreasing function of $D$, because $\mathrm{Y}^{*}$ and therefore $\mathrm{C}\left(\mathrm{Y}^{*}\right)$ decrease as $\mathrm{D}$ increases. Thus, if inequality (B6) is satisfied for $D_{0}$, it will also be satisfied for all $\mathrm{D}>\mathrm{D}_{\mathbf{0}}$. One of the initial assumptions was that trade is possible at the equilibrium witl compensatory damages. Hence, $D_{0}=V_{G}-$ $V_{D}$ satisfies (B6), and so must all larger values of $D$. 


\section{Appendix C}

Assume that sellers can produce two varieties of widgets, good widgets at a short-run variable cost of $\mathrm{C}_{\mathrm{g}}$, and bad widgets at a short-run variable cost of $\mathrm{C}_{b}$. There are $m$ sellers of good widgets and $M$ sellers of bad. Good widgets are worth $V_{g}$ to buyers; bad widgets are worth $V_{b}$. Of the buyers, $n$ pay $C$ to obtain the names of "good" sellers; N-n buy at random. Good widgets are worth making, i.e., $\mathrm{C}_{\mathrm{g}}-\mathrm{C}_{\mathrm{b}}<\mathrm{V}_{\mathrm{g}}-\mathrm{V}_{\mathrm{b}}$. Moreover, information is also worth buying, $\mathrm{C}<\mathrm{V}_{\mathrm{g}}-\mathrm{V}_{\mathrm{b}}$. The price is $\mathrm{p}$ for both types of widgets and $\mathrm{p}>\mathrm{C}_{\mathrm{g}}$.

A careful buyer's expected position is given by $B_{1}=V_{g}-p-C$. Since a careless buyer buys at random, his position is given by

$$
\text { (C1) } B_{2}=\left(V_{g^{-}} p\right) \cdot \frac{m}{M+m}+\left(V_{b}-p\right) \cdot \frac{M}{M+m}
$$

Reliable sellers share all of the careful buyers and get a share of the randomly shopping careless buyers. So the expected value of being a reliable seller (ignoring fixed costs) is

$$
\text { (C2) } S_{1}=\frac{n}{m} \cdot\left(p-C_{g}\right)+\frac{N-n}{m+M} \cdot\left(p-C_{g}\right) \text {. }
$$

The unreliable sellers share only the careless buyers, so their expected position $S_{2}=\frac{N-n}{M+1 n}\left(p-C_{b}\right)$. Being a careful buyer is worthwhile $\left(B_{1}>B_{2}\right)$ if and only if

$$
\text { (C3) }(M+m) \cdot\left(B_{1}-B_{z}\right)=M\left(V_{g}-V_{b}\right)-C \cdot(m+M)>0,
$$

or,

$$
\text { (C4) } \frac{M}{M+m} \cdot\left(V_{g}-V_{b}\right)>C \text {. }
$$

When this condition holds, $B_{1}>B_{2}$; thus no one will want to be a careless buyer, and hence $n=N$.

A similar analysis shows that sellers will be reliable $\left(S_{1}>S_{2}\right)$ if and only if

$$
\text { (C5) } S_{1}-S_{2}=\frac{n \cdot\left(p-C_{g}\right)+N-n}{M+m} \cdot\left(C_{b}-C_{g}\right)>0
$$

or,

$$
\text { (C6) } n(M+m)\left(p-C_{g}\right)>m(N-n)\left(C_{g}-C_{b}\right) \text {. }
$$


We now come to the point that there can be no reliable sellers of careful buyers. If any careful buyers existed, then $B_{1}>B_{2}$ and hence, assuming rationality, $n=N$. But now, from inequality (C6), $(\mathrm{M}+\mathrm{m})\left(\mathrm{p}-\mathrm{C}_{\mathrm{g}}\right)>\mathrm{O}$ is the condition necessary for it to be worthwhile to be a careful seller. Since we have assumed $\mathrm{p}>\mathrm{Cg}_{\mathrm{g}}$, this condition will always be satisfied; thus $S_{1}>S_{2}$. Hence, all sellers will be reliable and $M=0$. Substituting this value in inequality (C4) demonstrates that it no longer pays to be a careful buyer; thus, $n=0$. If $n=0$, however, the condition in (C6) no longer holds, and there are no reliable sellers. This contradiction establishes that there cannot be any reliable sellers. This being so, there is no point in being a careful buyer. Thus, the equilibrium state in this example contains no careful buyers and no reliable sellers. 